\title{
Progress of Plant Medicine Derived Extracts and Alkaloids on Modulating Viral Infections and Inflammation
}

This article was published in the following Dove Press journal: Drug Design, Development and Therapy

\author{
Huihui $\mathrm{Ti}^{1-3, *}$ \\ Zixi Zhuang ${ }^{4,5, *}$ \\ Qian $\mathrm{Yu}^{\prime}$ \\ Shumei Wang $2,3,6$
}

'School of Clinical Pharmacy, Guangdong Pharmaceutical University, Guangzhou, 510006, People's Republic of China; ${ }^{2}$ Key Laboratory of Digital Quality Evaluation of Chinese Materia Medica of State Administration of TCM, Guangdong Pharmaceutical University, Guangzhou, 510006, People's Republic of China; ${ }^{3}$ Engineering \& Technology Research Center for Chinese Materia Medica Quality of the Universities of Guangdong Province, Guangdong Pharmaceutical University, Guangzhou, 5I0006, People's Republic of China; ${ }^{4}$ Key Laboratory of Molecular Target \& Clinical Pharmacology, State Key Laboratory of Respiratory Disease, School of Pharmaceutical Sciences, Guangzhou Medical University, Guangzhou, 5I I436, People's Republic of China; ${ }^{5}$ Guangdong Institute of Analysis (China National Analytical Center, Guangzhou), Guangzhou, 510070, People's Republic of China; ${ }^{6} \mathrm{~S}$ chool of Traditional Chinese Medicine, Guangdong Pharmaceutical University, Guangzhou, 510006, People's Republic of China

*These authors contributed equally to this work
Correspondence: Qian Yu; Shumei Wang Email qyu@gdpu.edu.cn; gdpuwsm@I26. com

\begin{abstract}
Viral infectious diseases are serious threats to human health in both developing and developed countries. Although there is the continued development of new drugs from synthetic sources as antiviral agents, medicinal plants continue to provide the basic raw materials for some of the most important antiviral drugs. Alkaloids are a class of pharmacologically active plant compounds that are usually alkaline in nature. In this review, we tried to summarize recent progress in herb-based antiviral research, the advantages of using active plant compounds as antiviral agents, and the inflammatory responses initiated by alkaloids, based on the literature from 2009 to 2019, for the treatment of conditions, including influenza, human immunodeficiency virus, herpes simplex virus, hepatitis, and coxsackievirus infections. Articles are retrieved from PubMed, Google Scholar, and Web of Science using relevant keywords. In particular, the alkaloids from medicinal plants responsible for the molecular mechanisms of anti-inflammatory actions are identified and discussed. This review can provide a theoretical basis and approaches for using various alkaloids as antiviral treatments. More research is needed to develop alkaloidal compounds as antiviral therapeutic agents and potential regulators of the anti-inflammatory response.
\end{abstract}

Keywords: viral infectious diseases, alkaloids, antiviral, anti-inflammatory responses, antiviral therapeutic agents

\section{Introduction}

Viral infectious diseases are a serious threat to human health in both developing and developed countries ${ }^{1}$ and are responsible for the death of one million people worldwide each year. Viral diseases cause a substantial health burden with direct and indirect costs, including hospitalization and loss of productivity. ${ }^{2}$ The emergence of new diseases, such as the Zika virus and Chikungunya virus, previously unaffected has created significant concerns in healthcare. The pathogenesis of viral infections has provoked various types of complications that target different organs and the immune system and sometimes can even promote tumor progression. Most therapeutic regimens to date have emphasized broad, nonspecific approaches to treat viruses. As specific antiviral therapies become available, better diagnostic approaches to identify specific pathogens will be required. ${ }^{3}$

A considerable number of approved antiviral agents are vaccines, including vaccines against the various serotypes of influenza. However, the efficacy of antiviral vaccines is limited by antigenic drift or viral shift. ${ }^{4}$ Recently, synthetic drugs have been used as lifesaving treatments, ${ }^{5}$ although they are responsible for 
many harmful effects on the human body. One issue facing synthetic drugs is emerging drug resistance. Despite the development of new drugs from synthetic sources as antiviral agents, medicinal plants continue to provide the basic raw materials for some of the most important antiviral drugs. $^{6}$ Six natural alkaloid derivatives have been approved as antiviral drugs. Among them, tenofovir disoproxil is the orotate salt of a compound first approved as fumarate in $2001 .^{7}$ Natural products and natural product structures continue to play a highly important role in the antiviral drug discovery and development process. Among these, herbal essential oils are also continuously under investigation as potential new antiviral agents.

Alkaloids are a class of chemical compounds that are usually alkaline in nature and have at least one nitrogen atom in a heterocyclic ring. Alkaloids possess a wide range of biological activities including antimalarial, antiasthmatic, anticancer, antihypertensive, antispasmodic, antiarrhythmic, analgesic, antibacterial, and antidiabetic effects, as well as having CNS stimulant, muscle relaxant, and vasodilatory properties. ${ }^{8}$ According to their chemical structure, alkaloids can be divided into groups, including the piperidine alkaloids, isoquinoline alkaloids, indole alkaloids, terpenoid alkaloids, steroidal alkaloids, and quinoline alkaloids. There are numerous examples of bioactive alkaloids that are found both naturally and are available as synthetic products, including quinine, ephedrine, lobeline, theobromine, vincristine, vinblastine, serpentine, reserpine, ergotamine, nicotine, caffeine, vasicine, tubocurarine, curarine, atropine, aconitine, morphine, and piperine. Alkaloids are present in numerous plants. For example, piperidine alkaloids exist in many genera including Nicotiana, Conium, Lobelia, Pinus, Punica, Duboisia, Sedum, Withania, Carica, Hydrangea, Dichroa, Cassia, Prosopis, Genista, Ammodendron, Lupinus, Liparia, and Collidium. 9,10

In recent years, antiviral treatments using alkaloids have received increasing attention. Interestingly, many researchers have reported that alkaloids can be used to prevent and treat viral diseases. Additionally, alkaloids regulate human immune mechanisms to achieve viral resistance. They do not directly kill viral particles but instead function by promoting humoral immunity, type I IFN production, type I IFN signaling transduction, and other anti-inflammatory mechanisms. ${ }^{11}$ Therefore, this review mainly focuses on a summary of recent progress and advantages of herb-based antiviral research and various alkaloids related to anti-HIV, anti-HBV, anti-HCV, anti-IFV, anti-HSV, anti-enterovirus 71, etc. and the anti- inflammatory responses based on the literature from 2009 to 2019. The present review provides a comprehensive scientific summary of naturally occurring alkaloids that are pharmacologically active against viruses, and related anti-inflammatory effects. The authors hope that this review will provide new possibilities for the anti-virus new drug discovery from these alkaloids.

\section{Extracts and Alkaloids from Plants Modulating Viral Infections and Inflammation}

We performed a literature search using PubMed, Google Scholar, and Web of Science to identify completed and ongoing studies of various classes of alkaloids in viral diseases and publications focused on related antiinflammatory mechanisms of action (Table 1).

\section{Extracts and Alkaloids from Plants with Anti-Human Immunodeficiency Virus Type I (HIV-I) Infection Activity Extracts}

Panax ginseng Meyer (Korean Red Ginseng, KRG) belongs to the family Araliaceae. Korean ginseng has shown therapeutic efficacy toward various diseases, including cancer, diabetes, and atherosclerosis. A recent study has suggested that oral KRG can prolong survival in HIV-1 patients, possibly by slowing the decrease in $\mathrm{CD} 4^{+}$ T-cell counts. ${ }^{4}$ Two herbal decoctions (Betula alba and Sutherlandia frutescens) have interesting immunostimulatory and antimicrobial properties and hence could be useful in the management of HIV/AIDS and associated opportunistic infections. ${ }^{12}$ Chloroform and methanol extracts from the roots of Aerva lanata (Amaranthaceae family) showed inhibition of recombinant HIV reverse transcriptase (RT) $(91 \%$ and $89 \%$, respectively) at $1 \mathrm{mg} / \mathrm{mL} .{ }^{13}$ The findings of another study showed that coadministration of Moringa oleifera Lam. (Moringaceae family) leaf powder at traditionally used doses had no clinically significant effect on the steady-state pharmacokinetics of nevirapine in HIV-infected adults. ${ }^{14}$ In another study, Moringa oleifera Lam. leaf extracts showed potent and selective inhibition of the early stages in HIV-1 infectivity and this study partly explained the benefits and improvement in the quality of life claimed by people living with HIV/AIDS who use this medicinal plant as a supplement. ${ }^{15}$ Aqueous and $50 \%$ ethanolic extracts prepared from the stem bark of Acacia catechu (Mimosa 
Table I Medicinal Plants Used as Antiviral Agents

\begin{tabular}{|c|c|c|c|c|c|c|}
\hline No. & Plant Name & Plant Family & Part Used & Plant Extract Nature & Mechanism Involved (Model) & Ref. \\
\hline \multicolumn{7}{|c|}{ Anti-Human immunodeficiency virus type I (HIV-I): } \\
\hline 1 & $\begin{array}{l}\text { Panax ginseng Meyer } \\
\text { (Korean } \\
\text { Red Ginseng, KRG) }\end{array}$ & Araliaceae & Roots & Capsules & $\begin{array}{l}\text { Prolong survival in HIV-I patients, possibly by } \\
\text { slowing the decrease in CD } 4^{+} \text {T-cell count. }\end{array}$ & [4] \\
\hline 2 & Betula alba & Betulaceae & Leaves & Water & $\begin{array}{l}\text { Have interesting immunostimulatory and } \\
\text { antimicrobial properties and hence could be useful } \\
\text { in the management of HIVIAIDS and associated } \\
\text { opportunistic infections }\end{array}$ & [12] \\
\hline 3 & $\begin{array}{l}\text { Sutherlandia } \\
\text { frutescens }\end{array}$ & Fabaceae & Leaves & Water & $\begin{array}{l}\text { Have interesting immunostimulatory and } \\
\text { antimicrobial properties and hence could be useful } \\
\text { in the management of HIVIAIDS and associated } \\
\text { opportunistic infections }\end{array}$ & [12] \\
\hline 4 & Aerva lanata & Amaranthaceae & Roots & Chloroform and methanol & $\begin{array}{l}\text { Shows highest inhibition of recombinant HIV RT } \\
(91 \% \text { and } 89 \% \text { respectively) at } 1 \mathrm{mg} / \mathrm{mL} \\
\text { concentration. }\end{array}$ & [13] \\
\hline 5 & $\begin{array}{l}\text { Moringa oleifera } \\
\text { Lam. }\end{array}$ & Moringaceae & Leaves & $\begin{array}{l}\text { Methanol extract Ethyl } \\
\text { ether, methanol and water } \\
\text { extract }\end{array}$ & $\begin{array}{l}\text { Co-administration of leaf powder at the traditional } \\
\text { dose did not significantly alter the steady-state PK } \\
\text { of nevirapine in HIV-infected active against the HIV- } \\
\text { I lentiviral vector and inhibited the early events of } \\
\text { the viral replication cycle on HeLa cells in } \\
\text { a concentration dependent manner with } 1 C_{50} \text { of } \\
7.59 \mu \mathrm{g} / \mathrm{mL}, 7.72 \mu \mathrm{g} / \mathrm{mL} \text { and } 7.17 \mu \mathrm{g} / \mathrm{mL} \text {, } \\
\text { respectively. }\end{array}$ & {$[14,15]$} \\
\hline 7 & Acacia catechu & Mimosa & Stem bark & $\begin{array}{l}\text { Aqueous and } 50 \% \\
\text { ethanolic extracts }\end{array}$ & $\begin{array}{l}\text { A potential anti-HIV-I activity of A. catechu } \\
\text { mediated by the inhibition of the functions of the } \\
\text { viral protein and Tat. }\end{array}$ & [16] \\
\hline 8 & Phyllanthus emblica & Euphorbiaceae & Fruit & $\begin{array}{l}\text { n-hexane }(\mathrm{HX}) \text {, carbon } \\
\text { tetrachloride }(\mathrm{CT}) \text {, } \\
\text { chloroform }(\mathrm{CF}) \text {, and } \\
\text { aqueous fractions }\end{array}$ & $\begin{array}{l}\text { Anti-HIV activity via inhibition of HIV reverse } \\
\text { transcriptase activity }\end{array}$ & {$[17]$} \\
\hline 9 & $\begin{array}{l}\text { Sutherlandia } \\
\text { frutescens (L.) } \\
\text { R. Br. }\end{array}$ & Fabaceae & Leaves & $\begin{array}{l}\text { Ground to a uniform } \\
\text { powder }\end{array}$ & $\begin{array}{l}\text { Does not causes significant adverse effects in HIV } \\
\text { seropositive adults }\end{array}$ & [18] \\
\hline 10 & $\begin{array}{l}\text { Pinus yunnanensis } \\
\text { Franch }\end{array}$ & Pinaceae & Pine cones & $95 \%$ ethanol extract & $\begin{array}{l}\text { These data suggest that the pine cone extract from } \\
\text { Pinus yunnanensis } \\
\text { has potent inhibitory activities against HIV-I IIIB, } \\
\text { HIV-I } I_{\text {RF }} \text { RT inhibitor-resistant strains HIV-I } I_{A I 7} \text { and } \\
\text { HIV-I } I_{A O I 8} \text {, and HIV- } 2_{\text {ROD }} \text {, and its anti-HIV } \\
\text { mechanisms include inhibition of HIV entry and } \\
\text { inhibition of reverse transcriptase activity. }\end{array}$ & [19] \\
\hline 12 & $\begin{array}{l}\text { Alepidea } \\
\text { amatymbica }\end{array}$ & Umbelliferae & $\begin{array}{l}\text { Whole } \\
\text { plants }\end{array}$ & Aqueous extract & Showed significant selective anti-HIV activity & [20] \\
\hline 13 & $\begin{array}{l}\text { Plectranthus } \\
\text { barbatus Andr }\end{array}$ & Labiatae & Leaves & Ethanol extract & $\begin{array}{l}\text { Extract inhibited HIV-I PR and the IC } 50 \text { was } 62.0 \\
\mu \mathrm{g} / \mathrm{mL} \text {. and poor inhibition of HIV-I RT }\end{array}$ & [2I] \\
\hline 14 & $\begin{array}{l}\text { Sanguisorba } \\
\text { officinalis }\end{array}$ & Rosaceae & Stem & Water extract & Has anti-HIV-I properties & [22] \\
\hline
\end{tabular}


Table I (Continued).

\begin{tabular}{|c|c|c|c|c|c|c|}
\hline No. & Plant Name & Plant Family & Part Used & Plant Extract Nature & Mechanism Involved (Model) & Ref. \\
\hline 15 & $\begin{array}{l}\text { Schisandra } \\
\text { rubriflora }\end{array}$ & Magnoliaceae & Fruit & $\begin{array}{l}70 \% \text { aqueous acetone } \\
\text { extract }\end{array}$ & $\begin{array}{l}\text { Anti-HIV-I activity that showed inhibitory activity } \\
\text { on HIV-I IIIB induced syncytium formation }\end{array}$ & {$[23]$} \\
\hline 16 & $\begin{array}{l}\text { Schisandra } \\
\text { chinensis (Turcz.) } \\
\text { Baill. }\end{array}$ & Magnoliaceae & Fruit & $\begin{array}{l}\text { Petroleum ether and } \\
\text { EtOAc extract }\end{array}$ & Effects on HIV-I RT and viral replication. & {$[24]$} \\
\hline 17 & $\begin{array}{l}\text { Ephedra sinica } \\
\text { Stapf }\end{array}$ & Ephedraceae & Stem & Water extract & $\begin{array}{l}\text { Can induce the replication of latent HIV-linfected } \\
\text { Ulcells in vitro, through NF-KB activation }\end{array}$ & {$[25]$} \\
\hline \multicolumn{7}{|c|}{ Anti-hepatitis C virus (HCV): } \\
\hline 17 & Acacia nilotica & Fabaceae & Leaves & Methanol extract & $\begin{array}{l}\text { To substantiate strong antiviral activity against } \\
\text { HCV. }\end{array}$ & {$[36]$} \\
\hline 18 & Ruta angustifolia & Rutaceae & Leaves & Dichloromethane extract & $\begin{array}{l}\text { Had potent anti-HCV activity with } \mathrm{IC}_{50} \text { of } \mathrm{I} .6 \pm 0.3 \\
\mu \mathrm{g} / \mathrm{mL}\end{array}$ & {$[37]$} \\
\hline \multicolumn{7}{|c|}{ Anti-Influenza virus: } \\
\hline 19 & $\begin{array}{l}\text { Elderberry } \\
\text { (Sambucus nigra L.) }\end{array}$ & Caprifoliaceae & Berries & Concentrated juice & $\begin{array}{l}\text { Strong defense against IFV infection, and had } \\
\text { a beneficial effect by the stimulating immune } \\
\text { response and preventing viral infection. }\end{array}$ & {$[42]$} \\
\hline 20 & $\begin{array}{l}\text { Elderberry } \\
\text { (Sambucus nigra L.) }\end{array}$ & Caprifoliaceae & Berries & $\begin{array}{l}96 \% \text { ethanol purified } \\
\text { fractions obtained from } \\
50 \% \text { ethanol, and water } \\
\text { extracts }\end{array}$ & $\begin{array}{l}\text { Showed potent dose-dependent complement } \\
\text { fixating activity and macrophage stimulating activity, } \\
\text { might be responsible for the claimed effect of berry } \\
\text { extracts on cold and influenza, }\end{array}$ & {$[43,44]$} \\
\hline 21 & $\begin{array}{l}\text { Elderberry } \\
\text { (Sambucus nigra L.) }\end{array}$ & Caprifoliaceae & Flowers & $96 \% \mathrm{EtOH}$ extracts & $\begin{array}{l}\text { Posessed high complement fixating activity and } \\
\text { macrophage stimulating activity. }\end{array}$ & {$[45]$} \\
\hline \multicolumn{7}{|c|}{ Anti-Herpes simplex virus type (HSV): } \\
\hline 22 & $\begin{array}{l}\text { Mallotus peltatus } \\
\text { (Geist.) Mur. Arg. }\end{array}$ & Euphorbiaceae & Leaves & Methanolic crude extract & $\begin{array}{l}\text { The crude methanolic extract possessed weak anti- } \\
\text { HSV activity }\end{array}$ & {$[57]$} \\
\hline 23 & $\begin{array}{l}\text { Red marine alga } \\
\text { Osmundaria } \\
\text { obtusiloba (C. } \\
\text { Agardh) } \\
\text { R. E. Norris }\end{array}$ & Rhodomelaceae & & Acetone extract & $\begin{array}{l}\text { Demonstrated that both fractions had potent } \\
\text { inhibitory activity against HSV-I (herpes simplex } \\
\text { virus type I) and present low toxicity for cell } \\
\text { cultures }\end{array}$ & {$[58]$} \\
\hline 24 & $\begin{array}{l}\text { Phyllanthus urinaria } \\
\text { Linnea }\end{array}$ & Euphorbiaceae & Whole plant & Acetone-water & $\begin{array}{l}\text { Inhibited HSV-2 infection but not HSV-I infection. } \\
\text { inhibitor against HSV-2 and could potentially be } \\
\text { investigated for combinatorial drug treatment with } \\
\text { nucleoside analogues such as ACV in therapeutic } \\
\text { management of HSV-2 infection. }\end{array}$ & [59] \\
\hline 25 & Camellia sinensis & Theaceae & Whole plant & Aqueous extract & $\begin{array}{l}\text { Showed the most anti-Herpes property at } \\
\text { inhibition of HSV-I multiplication at one and } \\
\text { two hour that decreased at three hour. }\end{array}$ & {$[60]$} \\
\hline 26 & Echium amoenum $\mathrm{L}$ & Boraginaceae & Whole plant & Aqueous extract & $\begin{array}{l}\text { Had lowest anti-Herpes effect that at two hour } \\
\text { was similar antiviral property of Camellia sinensis at } \\
\text { three hour. }\end{array}$ & {$[60]$} \\
\hline
\end{tabular}


Table I (Continued).

\begin{tabular}{|c|c|c|c|c|c|c|}
\hline No. & Plant Name & Plant Family & Part Used & Plant Extract Nature & Mechanism Involved (Model) & Ref. \\
\hline 27 & $\begin{array}{l}\text { Melissa officinalis } \\
\text { Linn. }\end{array}$ & Labiatae & Leaves & Aqueous extract & $\begin{array}{l}\text { Exhibits low toxicity and affects attachment and } \\
\text { penetration of acyclovir-sensitive and acyclovir- } \\
\text { resistant HSVs in vitro }\end{array}$ & {$[61,62]$} \\
\hline 28 & Phyllanthus urinaria & Phyllanthus & Whole plant & Aqueous extracts & $\begin{array}{l}\text { Demonstrated the strongest antiviral activities } \\
\text { against HSV-I and HSV-2, with a SI value of more } \\
\text { than } 33.6\end{array}$ & [63] \\
\hline 29 & Phyllanthus watsonii & Phyllanthus & Whole plant & Aqueous extracts & $\begin{array}{l}\text { The first study that reported the antiviral activity } \\
\text { against herpes simplex virus type-I (HSV-I) and } \\
\text { HSV-2 in Vero cells }\end{array}$ & [63] \\
\hline 30 & Peganum harmala & Zygophyllaceae & Seed & Methanol extract & $\begin{array}{l}\text { Showed a virucidal action for HSV-2 activity, both } \\
\text { during the entry of viruses and the release of the } \\
\text { newly formed virions. }\end{array}$ & [64] \\
\hline \multicolumn{7}{|c|}{ Anti-Coxsackievirus $B_{3}$ (CVB3): } \\
\hline 31 & Rheum palmatum & Polygonaceae & $\begin{array}{l}\text { Roots } \\
\text { and rhizome }\end{array}$ & Ethanol extract & Its antiviral activities against $\mathrm{CVB}_{3}$ in vitro and in vivo & [78] \\
\hline \multicolumn{7}{|c|}{ Anti-Measles virus: } \\
\hline 32 & Cajanus cajan (L) & Leguminosae & Whole plant & $\begin{array}{l}\text { Aqueous and ethanol } \\
\text { extracts }\end{array}$ & Yielded higher activity against measles virus. & [80] \\
\hline
\end{tabular}

family) exhibited a dose-dependent inhibition of $\mathrm{HIV}-1_{\mathrm{NL} 4.3}$ at concentrations ranging from 0.1 to $10 \mu \mathrm{g} /$ $\mathrm{mL}$ mediated by the inhibition of the functions of the viral protein and Tat. ${ }^{16}$ Phyllanthus emblica (Euphorbiaceae family) fruit extracts have been found to exert their antiHIV activity via inhibition of HIV RT activity. ${ }^{17}$ The dried leaves of Sutherlandia frutescens (L.) R. Br. (Fabaceae family) did not change the HIV viral load, and the CD4 T-lymphocyte counts were similar in the two arms of a clinical study at 24 weeks. ${ }^{18}$ A pine cone extract from Pinus yunnanensis Franch (Pinaceae family) had potent inhibitory activities against $\mathrm{HIV}-1_{\mathrm{IIIB}}, \mathrm{HIV}-1_{\mathrm{RF}}$, RT inhibitor-resistant strains $\mathrm{HIV}-1_{\mathrm{A} 17}$ and $\mathrm{HIV}-1_{\mathrm{AO} 18}$, and HIV-2 $2_{\text {ROD }}$, and the anti-HIV mechanisms included inhibition of HIV entry and inhibition of reverse transcriptase activity. ${ }^{19}$ The aqueous extract from the whole plants of Alepidea amatymbica (Umbelliferae family) showed significant selective anti-HIV activity and was found to be non-toxic as judged by observing the cell density and morphology. ${ }^{20}$ A Plectranthus barbatus Andr (Labiatae family) leaf extract inhibited HIV-1 PR with an $\mathrm{IC}_{50}$ value of $62.0 \mu \mathrm{g} / \mathrm{mL}$ and showed poor inhibition of HIV$1 \mathrm{RT}^{21}$ A water extract from the stem of Sanguisorba officinalis (SOE, Rosaceae family) has anti-HIV-1 properties. SOE acted directly on HIV-1, instead of the cellular receptors or coreceptors, and exhibited potency against replication-competent HIV-1 strains resistant to specific drugs targeting protease and RT activities. ${ }^{22}$ Two members of the Magnoliaceae family, Schisandra rubriflora and Schisandra chinensis (Turcz.) Baill., have anti-HIV-1 activity. A 70\% aqueous acetone extract of Schisandra rubriflora fruits showed inhibitory activity on HIV-1 $1_{\text {IIIB }}$ induced syncytium formation. ${ }^{23}$ The petroleum ether and ethyl acetate extracts of the fruits of Schisandra chinensis (Turcz.) Baill. had effects against HIV-1 RT and viral replication. $^{24}$ The water extract of the stem of Ephedra sinica Stapf (Ephedraceae family) could induce the replication of latent HIV-1 infected-U1 cells in vitro through NF- $\kappa$ B activation $^{25}$ (Table 1).

\section{Essential Oils}

Leoheo domatiophorus Chaowasku, D.T. Ngo and H.T. Le. L. domatiophorusis a medium-sized to large trees shrub species, are widely distributed in rainforests of central Vietnam. Le et al have reported that the essential oil resulted in being completely ineffective against tested viruses HIV-1 with EC50 values over $100 \mu \mathrm{g} / \mathrm{mL} .{ }^{26}$ Paramignya trimera (Oliv.) Guillaum is a woody species and is widely distributed in the South of Vietnam. Limnocitrus littoralis Swingle is a knotty shrub species, naturally distributed in Indonesia 
and Vietnam. The parts of L. littoralis have been used to treat fevers and colds in Vietnamese traditional medicine. The oils isolated from $P$. trimera and L. littoralis were completely ineffective against HIV-1 viruses. ${ }^{27}$ Atalantia sessiliflora is one of the species of the genus Atalantia found in Vietnam. The oil was completely ineffective against tested HIV-1 viruses. ${ }^{28}$

\section{A Quinolizidine-Type Alkaloid}

Sophora alopecuroides L. is a medicinal plant widely distributed in Western and Central Asia, especially in China. Sophora alopecuroides L. has been used for decades to treat fever, bacterial infections, heart disease, rheumatism, and gastrointestinal diseases. Aloperine (1), a quinolizidine-type alkaloid, was first isolated from the seeds and leaves of Sophora alopecuroides L. To evaluate the anti-HIV activity of aloperine, HIV-1 NL4-3 NanoLucsec virus infection of MT4 cells was performed in the presence of various concentrations of aloperine. Aloperine showed anti-HIV activity with an $\mathrm{EC}_{50}$ value of $1.75 \pm 0.59 \mu \mathrm{M}$. BMS-806-resistant, Env-mediated cellcell fusion, such as that mediated by YU2-T198P and 8x, may be inhibited by aloperine. ${ }^{29}$

\section{An Isoquinoline-Type Alkaloid}

Emetine (2) is an alkaloid that possesses a monoterpenoidtetrahydroisoquinoline skeleton. Emetine occurs in three plant families, including Alangiaceae, Icacinaceae, and Rubiaceae, and the major source of emetine is Psychotria ipecacuanha Stokes (Rubiaceae). Emetine is an anti-HIV agent that blocks HIV-1 infection in primary and established cells at noncytotoxic levels and its effects are mediated by reverse transcription inhibition. Emetine also blocked HIV-1 infection of a variant strain harboring an NRTI-resistance mutation. ${ }^{30}$ The isoquinoline alkaloids laurolitsine (norboldine, $\mathbf{3}$ ) isolated from the family Lauraceae belong to the aporphinic group, which contain only one benzyl tetrahydroisoquinoline group. Laurolitsine showed a significant inhibitory effect on HIV-1 integrase with an $\mathrm{IC}_{50}$ value of $16.3 \mathrm{mM} .^{31,32}$

\section{Quinoline-Type Alkaloids}

Buchapine (4), a quinoline alkaloid, was isolated from a methanolic extract of the epigeal parts of Haplophyllum bucharicum, Haplophyllum tuberculatum, and Euodia roxburghiana. 3-(3-Methyl-2-butenyl)-4-[(3-methyl-2-butenyl) oxy]-2(1H)-quinolinone (5) was also isolated from H. tuberculatum and E. roxburghiana. Compounds $\mathbf{4}$ and $\mathbf{5}$ exhibited anti-HIV activities against HIV-1 in cultured human lymphoblastoid CEM-SS cells with $\mathrm{IC}_{50}$ values of $29.0 \mu \mathrm{M}$ and $26.9 \mu \mathrm{M}$, respectively. Buchapine derivatives of quinoline 2,4-diol were synthesized and tested for their anti-HIV potential in the human CD4+ T cell line CEM-GFP. Compounds 6-9 have displayed good anti-HIV activities with $\mathrm{IC}_{50}$ values of $8.76,11.60,8.95$, and $19.34 \mu \mathrm{M}$, respectively. ${ }^{33}$ The methanol extract of Melochia odorata yielded four quinoline alkaloids, including waltherione A (10) and waltherione A (11). Compounds $\mathbf{1 0}$ and $\mathbf{1 1}$ showed significant antiviral activity in an in vitro anti-HIV cytoprotection assay at concentrations of 56.2 and $0.83 \mu \mathrm{M}$, respectively, and inhibited HIV P24 formation by more than $50 \%$ at concentrations of 1.7 and $0.95 \mu \mathrm{M}$, respectively ${ }^{34}$ (Figure 1).

\section{Extracts and Alkaloids from Plants with Anti-HBV Infection Activity Matrine-Type Alkaloids}

Sophora flavescens is a species of plant in the genus Sophora. $\mathrm{Ku}$ shen (the root) or kushenin (a flavonoid compound) are typical traditional Chinese medicines that are derived from this plant. Sophora flavescens is commonly used for the treatment of viral hepatitis, cancer, viral myocarditis, gastrointestinal hemorrhage, and skin diseases (such as colpitis, psoriasis, and eczema). Five matrine-type alkaloids, flavesine G (12), flavesine J (13), alopecurine B (14), oxymatrine (15), and sophoridine (16), were isolated from the roots of Sophora flavescens. Compounds 12-16 were evaluated for their anti-HBV activities in HepG2.2.15 cells. Compounds 12-16 significantly inhibited HBsAg secretion by $37.2 \%$, 44.3\%, $46.0 \%, 38.3 \%$, and $40.2 \%$, respectively, at noncytotoxic concentrations of 0.2 or $0.4 \mathrm{mM}$, which suggested that these alkaloids had comparable potencies to matrine (34.7\% at a concentration of $1.0 \mathrm{mM}$ ), and were more active than the positive control lamivudine $(31.5 \%$ at a concentration of $1.0 \mathrm{mM}){ }^{35}$ Five matrine-type alkaloid dimers, flavesine A (17), flavesine B (18), flavesine D (19), and flavesine E (20), were isolated from the roots of Sophora flavescens. Compounds 17-20 were evaluated for their anti-HBV activities in HepG2.2.15 cells using real-time PCR. The results revealed that compounds 17-20 exhibited inhibitory effects on the expression of HBV DNA in HepG2.2.15 cells with $\mathrm{IC}_{50}$ values of $44.85 \pm 7.30,86.60 \pm 4.30,74.28 \pm 0.31$, and $70.62 \pm$ $0.93 \mu \mathrm{M}$, respectively, while the $\mathrm{IC}_{50}$ value of the positive control PFA (foscarnet) was $105.53 \pm 8.57 \mu \mathrm{M}^{36}$ Three matrine-based alkaloids, sophaline B (21), sophaline C (22), and sophaline D (23), were isolated from the 
<smiles>C1=C2CCCN[C@H]2[C@H]2C[C@@H]3CCCCN3C[C@H]12</smiles>

1<smiles>CC(C)=CCOc1c(CC=C(C)C)c(=O)[nH]c2ccccc12</smiles>

5<smiles>C#CCCOC1CC(O)Nc2ccccc21</smiles>

9<smiles>CC[C@H]1CN2CCc3cc(OC)c(OC)cc3[C@@H]2C[C@H]1CNCCc1ccc(OC)c(OC)c1</smiles>

2<smiles>CC(C)=CCOC1c2ccccc2NC1O</smiles>

6

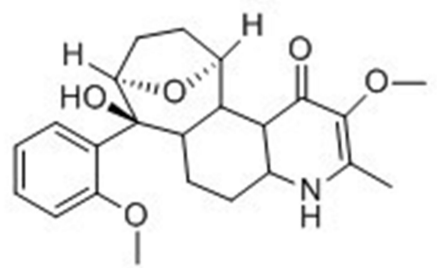

10<smiles>COc1cc2c(cc1O)-c1cc(OC)c(O)cc1CCN2</smiles>

3<smiles>C#CCCC1C(O)Nc2ccccc2C1OCC#C</smiles>

7<smiles>COc1c(C)[nH]c2ccc3c(c2c1=O)[C@H]1CCC[C@]3(c2ccccc2)O1</smiles>

11

Figure I Chemical structures of natural plant alkaloids with anti-HIV properties.

seeds of Sophora alopecuroides. Compound 21 possesses a previously unknown 6/5/6/6 ring system. Compounds 21-23 were tested for their antiviral activities against HBV in HepG2.2.15 cells. The results of the assays showed that compounds 21-23 significantly inhibited HBsAg secretion by more than $50 \%$ at noncytotoxic concentrations of 0.2 or $0.4 \mathrm{mM}^{37}$

\section{Steroidal-Type Alkaloids}

Solanum erianthum D. Don, a medicinally important plant of Solanaceae, contains steroidal alkaloids. The steroidal alkaloid glycoside solamargine (24) was isolated from the methanolic extract of the leaves of Solanum erianthum D. Don. Compound 24 demonstrated strong inhibition of the DNA replication of $\mathrm{HBV}$ with an $\mathrm{IC}_{50}$ value of $2.17 \mu \mathrm{M}$, and also showed potent activity against $\mathrm{HBs} A g$ with an $\mathrm{IC}_{50}$ value of $1.57 \mu \mathrm{M}$. Compound 24 is a promising lead molecule in the search for drugs with multiple mechanisms for the treatment of $\mathrm{HBV}^{38}$ (Figure 2).

\section{Extracts and Alkaloids from Plants with Anti-Hepatitis C Virus (HCV) Infection Activity Extracts}

Acacia nilotica belongs to the family Fabaceae. A methanolic extract from the leaves of Acacia nilotica had strong antiviral activity against hepatitis $\mathrm{C}$ virus (HCV). ${ }^{39}$ A dichloromethane extract of Ruta angustifolia leaves had a potent anti-HCV activity with an $\mathrm{IC}_{50}$ value of $1.6 \pm 0.3 \mu \mathrm{g} / \mathrm{mL}^{37}$ (Table 1 ).

\section{Quinoline-Type Alkaloids}

Ruta graveolens L., belonging to the Rutaceae family, is a medicinal plant widely used in the Mediterranean region to treat pain, dermatitis, rheumatism, and other 
<smiles>O=C(O)CCCc1ncc2c3c1CCCN3CCC2</smiles>

12<smiles>O=C(CCCc1ncc2c3c1CCCN3CCC2)N1CCCCC1</smiles>

13<smiles>O=C1CCCN2CCCC(O)(C3(O)CCCN4CCCCC43)C(=O)CN12</smiles>

14

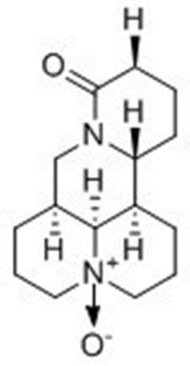

15

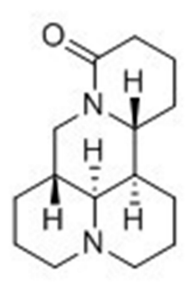

16

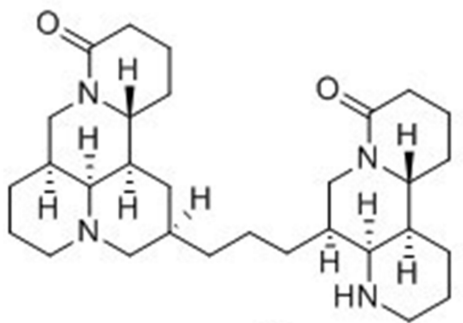

17

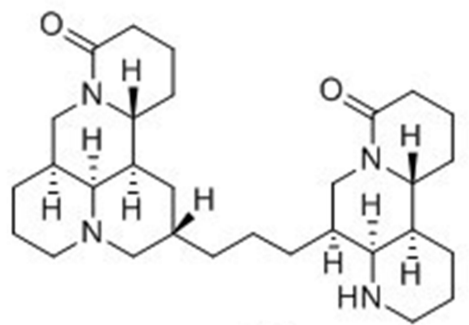

18

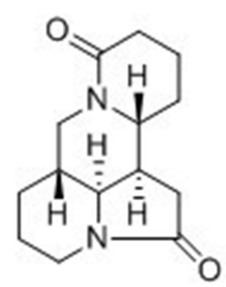

21

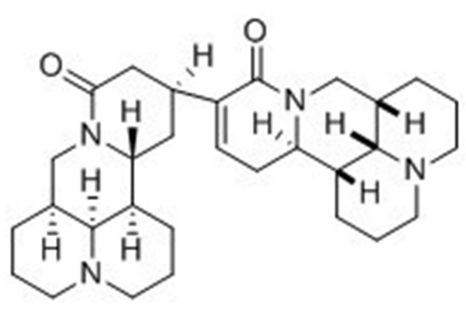

19

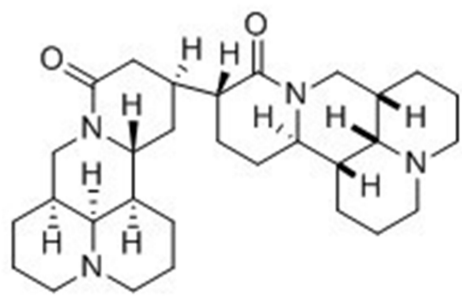

20

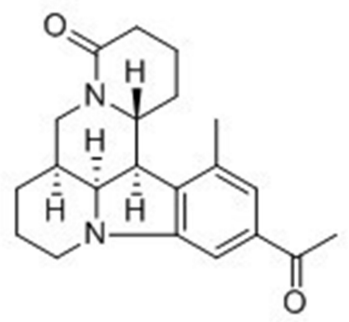

22

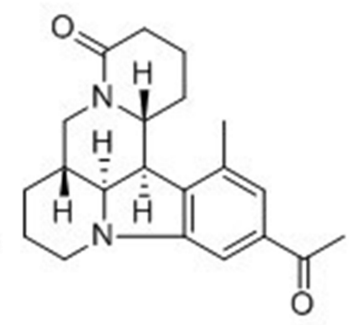

23

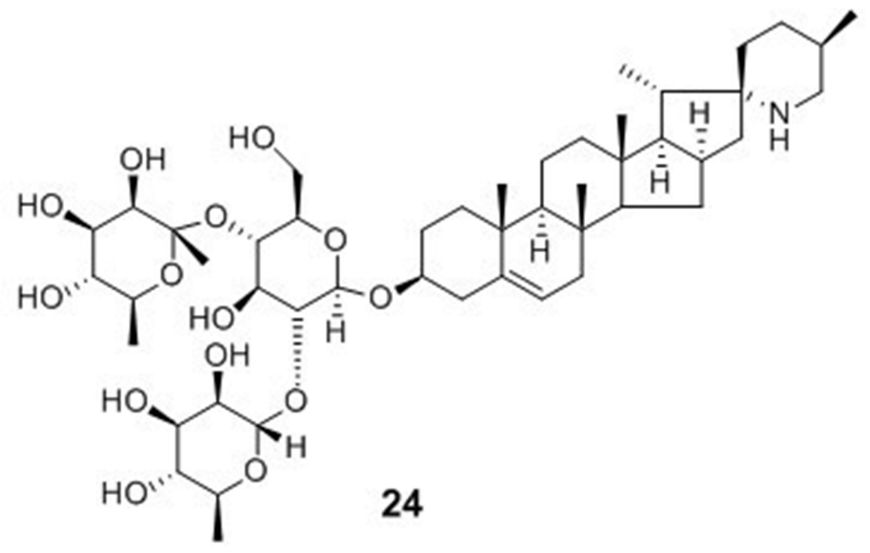

Figure 2 Chemical structures of natural plant alkaloids with anti-HBV properties.

inflammatory diseases. Pseudane IX (25), arborinine (26), and kokusaginine (27) were isolated from the leaves of Ruta angustifolia. Pseudane IX showed strong anti-HCV activity with an $\mathrm{IC}_{50}$ value of $1.4 \pm 0.2 \mu \mathrm{M}$ without apparent cytotoxicity. The anti-HCV activity of pseudane
IX was stronger than that of ribavirin $(2.8 \pm 0.4 \mu \mathrm{M})$, which has been widely used for the treatment of $\mathrm{HCV}$ infections. Mode-of-action analyses revealed that pseudane IX inhibited $\mathrm{HCV}$ at the post-entry step and decreased the levels of HCV RNA replication and viral 
protein synthesis. Compounds $\mathbf{2 6}$ and $\mathbf{2 7}$ also possessed moderate anti-HCV activity with $\mathrm{IC}_{50}$ values of $6.4 \pm 0.7$ and $6.4 \pm 1.6 \mu \mathrm{M}$, respectively. ${ }^{40}$

\section{Quinolizidine-Type Alkaloids}

Myrioneuron alkaloids are a family of nitrogen-containing polycyclic compounds produced by plants of the genus Myrioneuron R. Br. (Rubiaceae). Two pairs of enantiomers, cluster A (28) and cluster B (29), as well as the cluster A derivative ( \pm )-13 $\alpha$-methoxymyrifabral A (30) were isolated from the aerial parts of Myrioneuron faberi. Cluster A (28) and cluster B (29) possess a cyclohexanefused octahydroquinolizine skeleton. Compounds 28-30 inhibited replication of $\mathrm{HCV}$ with $\mathrm{IC}_{50}$ values of 4.7, 2.2, and $0.9 \mu \mathrm{M}$, respectively, and exhibited less cytotoxicity against liver cells than the positive control telaprevir (VX950). ${ }^{41}$ Aloperine (1), a quinolizidine alkaloid with an unusual endocyclic ring system, was extracted from Sophora alopecuroides. Aloperine has been identified as a potent $\mathrm{HCV}$ inhibitor with an $\mathrm{EC}_{50}$ value of $4.23 \pm 0.99$ $\mu \mathrm{M}$. 12N-4'-Methylpiperazine-1'-sulfonyl aloperine (31), based on aloperine as the lead compound, was synthesized and evaluated for its anti-HCV activity. Compound $\mathbf{3 1}$ exhibited moderate potency with $\mathrm{EC}_{50}$ values in the micromolar range against both wild-type and direct-acting antiviral agent (DAA)-resistant variants, and synergistically inhibited HCV replication in conjunction with approved DAAs. Furthermore, compound $\mathbf{3 1}$ also had a good oral pharmacokinetic and safety profile. ${ }^{42}$

\section{Isoquinoline-Type Alkaloids}

Berberine (BBR, 32) is an isoquinoline alkaloid that has been isolated from several plants belonging to the Berberis genus and is a traditional component of Chinese and Ayurvedic medicine. BBR is a potent $\mathrm{HCV}$ entry inhibitor that specifically impedes HCVcc attachment and entry/fusion steps without inactivating the free virus particles or affecting the expression of host cell entry factors and post-entry viral replication. BBR also effectively inhibited infection by viral pseudoparticles expressing HCV E1/E2 glycoproteins, and molecular docking analysis pointed at a potential interaction with HCV E2. In addition, BBR suppressed HCVcc infection of primary human hepatocytes. ${ }^{43}$

\section{Matrine-Type Alkaloids}

IMB-DM122 (33) was designed and semi-synthesized using matrine as the lead compound. Compound $\mathbf{3 3}$ was found to be an effective and safe inhibitor of Hsc70 mRNA/protein expression in human hepatocytes. Compound $\mathbf{3 3}$ inhibited
HCV replication through the destabilization of Hsc70 mRNA, and the half-life of host Hsc70 mRNA was reduced by $78 \%$ after treatment with $\mathbf{3 3}$. Compound $\mathbf{3 3}$ appeared to be highly efficient at inhibiting Hsc70-related HCV replication. In addition, compound $\mathbf{3 3}$ showed a good safety profile in vitro as well as in vivo with no indication of harmful effects on liver and kidney functions ${ }^{44}$ (Figure 3).

\section{Extracts and Alkaloids from Plants with Anti-Human Influenza a Virus (IFV) Infection Activity \\ Extracts}

Elderberry (Sambucus nigra L.) belongs to the family Caprifoliaceae and has traditionally been used for treating influenza and colds. The concentrated juice of elderberry stimulated the immune response and prevented viral infection in human influenza A virus (IFV)-infected mice. ${ }^{45}$ The berries of Sambucus nigra L. are traditionally used to treat respiratory illnesses, such as colds and influenza. The fractions obtained from $50 \%$ ethanol and water extracts showed potent dose-dependent complement fixating activity and macrophage stimulating activity. Studies have also indicated that elderberry's effectiveness against infection may be attributed to immune stimulation. ${ }^{46,47}$ The flowers of Sambucus nigra L. (elderflowers) are traditionally used for their anti-inflammatory properties. The $96 \%$ EtOH extracts from elderflowers possessed high complement fixating activity and macrophage stimulating activity ${ }^{48}$ (Table 1).

\section{Isoquinoline-Type Alkaloids}

BBR (32), a natural isoquinoline alkaloid, has been evaluated for its antiviral effect against influenza $\mathrm{H} 1 \mathrm{~N} 1$ in vivo and in vitro. The results showed that BBR strongly suppressed viral replication in A549 cells and in mouse lungs. BBR also relieved pulmonary inflammation and reduced necrosis, inflammatory cell infiltration, and pulmonary edema induced by a viral infection in mice when compared with vehicle-treated mice. BBR suppressed the viral infection-induced up-regulation of components of the TLR7 signaling pathway, such as TLR7, MyD88, and NF- $\kappa B$ (p65), at both the mRNA and protein levels. Furthermore, BBR significantly inhibited the viral infection-induced increases in Th1/Th2 and Th17/Treg ratios, as well as the production of inflammatory cytokines. ${ }^{49}$ BBR exhibited antiviral effects on the influenza virus both in vitro and in vivo. The possible therapeutic mechanism of BBR on influenza-induced viral pneumonia might be through inhibition of the virus infection, as well as 
<smiles>CCCCCCCCCc1cc(=O)c2ccccc2[nH]1</smiles>

25<smiles>CCN(CC)CC12CC3CCCC(C3)C(C3CCCCN3C1)C2O</smiles>

29<smiles>COC1C=c2c(=O)c3ccccc3n(C)c2=CC1OC</smiles>

26

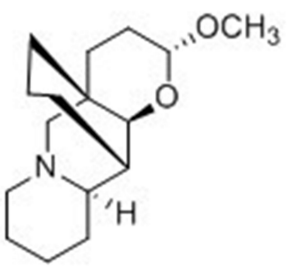

30<smiles>COc1cc2nc3occc3c(OC)c2cc1OC</smiles>

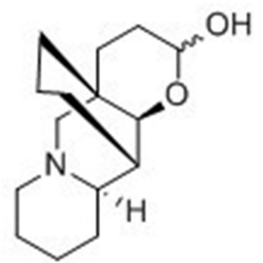

27<smiles>CN1CCN(S(=O)(=O)N2CCCC3=C[C@H]4C[C@H]5CCCCN5C[C@H]4[C@H]32)CC1</smiles>

31<smiles>COc1ccc2cc3c(cc2c1OC)[N+]1=CCC2=CC4=C(C=C2C4=C1)OCO3</smiles>

32<smiles>COc1ccc(CN2CC3CCCN4CCCC(C4CCCC(=O)O)C32)cc1</smiles>

33

Figure 3 Chemical structures of natural plant alkaloids with anti-hepatitis $C$ virus properties.

improvements in the pathogenic changes by repressing the release of inflammatory substances. ${ }^{50}$

Papaver rhoeas is a species of flowering plant in the poppy family. Chelianthifoline (34), isolated from the ethyl acetate fraction of Korean Papaver rhoeas bee pollen, displayed noncompetitive inhibition of H3N2 neuraminidase. Furthermore, compound 34 reduced the severity of virally induced cytopathic effects. ${ }^{51}$ Trolline (35) is a representative alkaloid from Trollius chinensis. Compound 35 provided an anti-H1N1 viral effect by partially down-regulating the TLR3 and 7 pathways and upregulating the TLR4 pathway. ${ }^{52}$

\section{Indole-Type Alkaloids}

Isatis indigotica is an important medicinal plant in China. The dried leaves and roots of Isatis indigotica are widely used in traditional Chinese medicine for curing diseases caused by bacteria and viruses, such as influenza and viral pneumonia. Isatibisindosulfonic acid B (36) and isatindosulfonic acid B (37), two indole alkaloid sulfonic acids, were isolated from an aqueous extract of the Isatis indigotica root. Compounds $\mathbf{3 6}$ and 37 showed antiviral activities against the $\mathrm{H} 3 \mathrm{~N} 2$ influenza virus with $\mathrm{IC}_{50}$ values of 33.3 and $33.3 \mu \mathrm{M}$, respectively, and the coxsackievirus B3. ${ }^{53}$ Three glycosidic bisindole alkaloids, isatindigobisindoloside B (38), isatindigobisindoloside E (39), and isatindigobisindoloside $\mathrm{F}$ (40), were isolated from an aqueous extract of the Isatis indigotica root. Compounds 38-40 showed antiviral activities against both the H3N2 influenza virus and coxsackievirus B3. ${ }^{54}$ Five indole alkaloids, oxoglyantrypine (41), norquinadoline A (42), deoxynortryptoquivaline (43), deoxytryptoquivaline (44), and tryptoquivaline (45), 
were isolated from a culture of the mangrove-derived fungus Cladosporium sp. PJX-41. Compounds 41-45 exhibited significant activity against influenza virus A (H1N1), with $\mathrm{IC}_{50}$ values of $85,82,87,85$, and 89 $\mu \mathrm{M}$, respectively. ${ }^{55}$

\section{A Pyrrole-Type Alkaloid}

Epigoitrin (46) is the main alkaloid compound isolated from the wood root of Isatis indigotica. Epigoitrin exerts its anti-influenza activity by blocking the virus attachment. ${ }^{56}$ Epigoitrin has been shown to reduce the susceptibility to influenza virus via mitochondrial antiviral signaling. ${ }^{57}$

\section{An Amphetamine-Type Alkaloid}

Ephedra herbs were used extensively for food and medicine by the Native Americans of the Southwest, especially in dry desert areas. Ephedrine (47) alkaloid-free Ephedra herb extracts have anti-influenza virus activity as shown by the inhibition of MDCK cells infected with the H1N1 influenza virus. $^{25}$

\section{A Sesquiterpenoid-Type Alkaloid}

Dendrobium nobile is a medicinal plant from Guizhou province, China. Dendrobine (48), a major component of Dendrobium nobile, possessed antiviral activity against influenza A viruses, including A/FM-1/1/47 (H1N1), A/Puerto Rico/8/34 H274Y (H1N1), and A/ Aichi/2/68 (H3N2) with $\mathrm{IC}_{50}$ values of $3.39 \pm 0.32$, $2.16 \pm 0.91$, and $5.32 \pm 1.68 \mu \mathrm{M}$, respectively. Compound 48 inhibited early steps in the viral replication cycle and could bind to the highly conserved region of the viral nucleoprotein, subsequently restraining nuclear export of the viral nucleoprotein and its oligomerization $^{58}$ (Figure 4).

\section{Extracts and Alkaloids from Plants with Anti-Respiratory Syncytial Virus Infection Activity}

Four diterpenoid alkaloids, ajacisine C (49), ajacisine $\mathrm{D}(\mathbf{5 0})$, ajacisine $\mathrm{E}$ (51), and isodelectine (52), were isolated from Delphinium ajacis. Compounds 49-52 were evaluated for their in vitro antiviral activities against the respiratory syncytial virus, and compounds 49-52 exhibited moderate to weak effects with $\mathrm{IC}_{50}$ values of $75.2 \pm$ $1.1,35.1 \pm 0.6,10.1 \pm 0.3$, and $50.2 \pm 0.5 \mu \mathrm{M}$, respectively ${ }^{59}$ (Figure 5).

\section{Extracts and Alkaloids from Plants with Anti-Herpes Simplex Virus (HSV) Infection Activity Extracts}

Mallotus peltatus (Geist.) Mur. Arg belongs to the family Euphorbiaceae. A methanolic crude extract of Mallotus peltatus leaves possessed weak anti-herpes simplex virus (HSV) activity. Conversely, an active fraction A exhibited potent anti-HSV activity against both HSV-1 $\left(\mathrm{EC}_{50}=7.8\right.$ $\mu \mathrm{g} / \mathrm{mL})$ and HSV-2 $\left(\mathrm{EC}_{50}=8.2 \mu \mathrm{g} / \mathrm{mL}\right)$, probably by inhibiting the early stage of multiplication. ${ }^{60}$ The red marine alga Osmundaria obtusiloba (C. Agardh) R. E. Norris treated with acetone had potent antiviral activity against HSV-1 and HSV-2 and showed low toxicity toward cell cultures. Although acyclovir has better activity than the algal extract, inhibitors that impact the different steps of viral infection are desirable because they may allow more efficient treatment and prevent the emergence of resistant strains. ${ }^{61}$ Phyllanthus urinaria linnea (Euphorbiaceae family) is a traditional medicinal plant used to treat various diseases. An acetone extract of the whole plant of P. urinaria inhibited HSV-2 infection, but not HSV-1 infection. As an entry inhibitor against HSV-2, this extract could potentially be investigated for combinatorial drug treatment with nucleoside analogs, such as ACV, for the therapeutic management of HSV-2 infections. ${ }^{62}$ A Camellia sinesis (Theaceae family) aqueous extract of the whole plant was tested for antiviral activity against HSV. The results showed that HSV-1 multiplication was inhibited at 1 and $2 \mathrm{~h}$ after treatment and was decreased at $3 \mathrm{~h}$. An aqueous extract of the whole plant of E. amoenum, which belongs to the family Boraginaceae, had a low antiherpes effect at $2 \mathrm{~h}$ after treatment, which was similar to the antiviral properties of $C$. sinesis at $3 \mathrm{~h}$. C. sinesis and $E$. amoenum extracts showed the best antiherpes effect when used $1 \mathrm{~h}$ after virus inoculation. ${ }^{63}$ An aqueous extract of Melissa officinalis Linn (Labiatae family) was examined for its antiviral activity against acyclovirsensitive HSV-1 and clinical isolates of acyclovirresistant strains in vitro. The Melissa extract interacted directly with free viral particles of two acyclovir-resistant HSV strains with low $\mathrm{IC}_{50}$ values and high selectivity indices (SI). The Melissa extract inhibited HSV-1 attachment to host cells in a dose-dependent manner for acyclovir-sensitive and acyclovir-resistant strains. ${ }^{64,65}$ The whole plant of two Phyllanthus family members, Phyllanthus urinaria and Phyllanthus watsonii, demonstrated strong 
<smiles>COc1cc2c(cc1O)[C@H]1Cc3ccc4c(c3CN1CC2)OCO4</smiles>

32<smiles>N#CC(c1c[nH]c2ccccc12)S(=O)(=O)O</smiles>

37<smiles>N#C[C@H](c1[nH]c2ccccc2c1OC1OCC(O)C(O)C(CO)O1)c1c[nH]c2ccccc12</smiles>

38<smiles>O=C1CCC2c3cc(O)c(O)cc3CCN12</smiles>

35<smiles>O=C1c2ccccc2NC1(O)C(O)(O)c1c[nH]c2ccccc12</smiles>

36

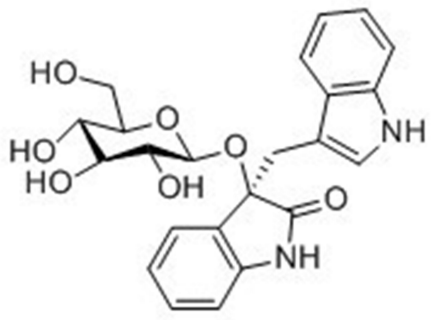

39<smiles>CNC(C)C(O)c1ccccc1</smiles>

46

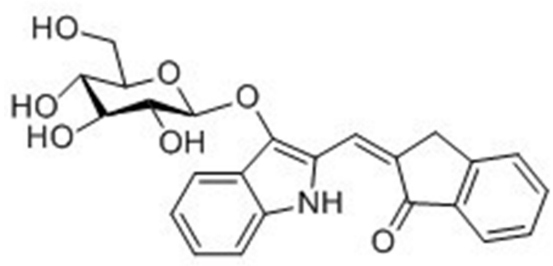

40<smiles>O=C1NC(=O)[C@H](Cc2c[nH]c3ccccc23)n2c1nc1ccccc1c2=O</smiles>

41<smiles>CC(C)=C1NC(=O)C(CC2(O)c3ccccc3N3C(=O)C(C)NC32)C2C(=O)c3ccccc3N=C12</smiles>

42<smiles>C=CC1CNC(=S)O1</smiles>

47<smiles>CC(=O)O[C@H](C1=NC2=CC=CCC2C(=O)N1[C@H]1C(=O)OC[C@]12c1ccccc1N1C(=O)[C@H](C)N[C@H]12)C(C)C</smiles>

43<smiles>CC(=O)O[C@@H](C1=NC2=CC=CCC2C(=O)N1[C@H]1[C@H]2NC(C)(C)C(=O)N2c2ccccc2[C@]12OC(=O)[C@H]2C)C(C)C</smiles>

44

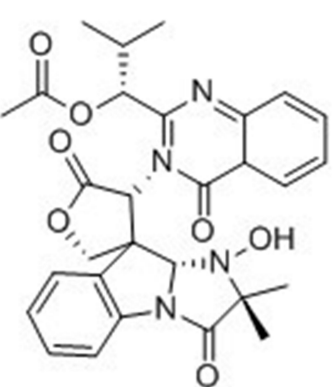

45

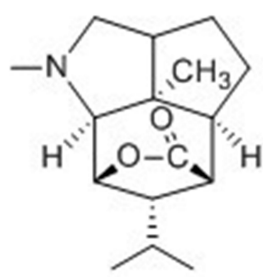

48

Figure 4 Chemical structures of natural plant alkaloids with anti-influenza virus properties.

antiviral activity against HSV-1 and HSV-2 with an SI $>33.6$. Time-of-addition studies suggested that the extract may act against both the early infection and replication stages. Protein expression studies indicated that $P$. urinaria demonstrated potent inhibitory activity against HSV. ${ }^{66}$
Peganum harmala (Zygophyllaceae family) was investigated for its HSV-2 activity and organic extracts of the different plant organs were evaluated for their cytotoxicity toward Vero cells by the MTT test and anti-HSV-2 activity by a plaque reduction assay. Only the methanol seed 


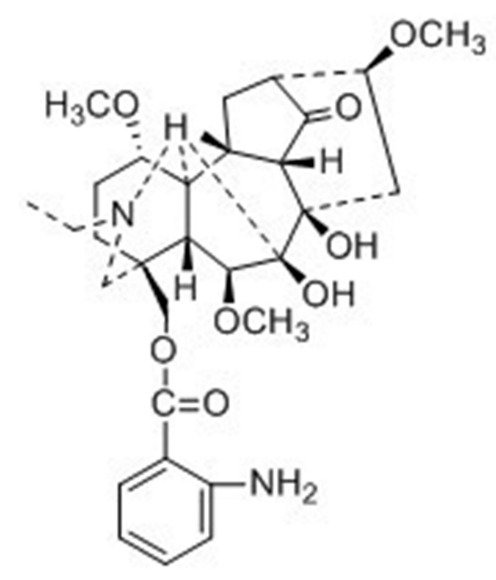

49

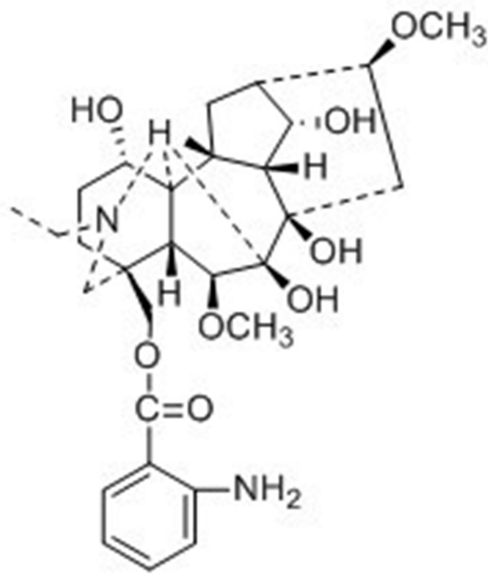

50

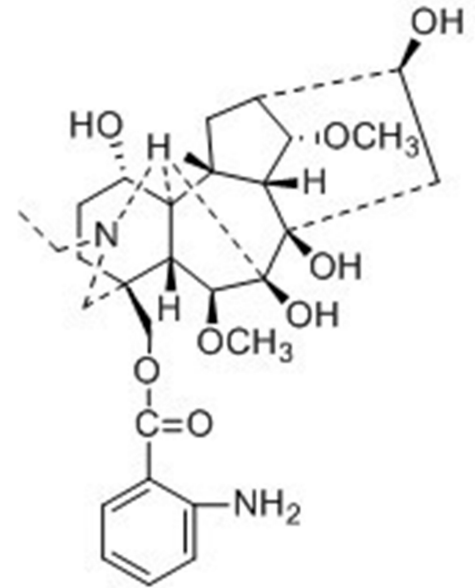

51

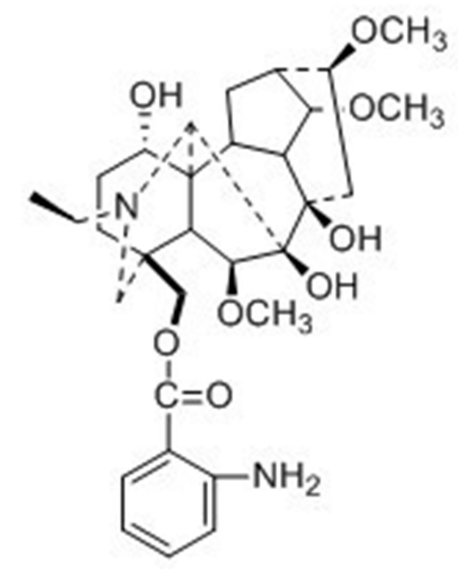

52

Figure 5 Chemical structures of natural plant alkaloids with anti-respiratory syncytial virus properties.

extract was active with an $\mathrm{IC}_{50}$ value of $13.2 \mu \mathrm{g} / \mathrm{mL}$ and $\mathrm{SI}$ of 161. Additionally, a study of the antiviral mode of action revealed that this extract exerted a virucidal action during both the viral entry and the release of the newly formed virions; however, no cell protection was observed $^{67}$ (Table 1).

\section{Essential Oils}

Researchers have reported that essential oils isolated from Leoheo domatiophorus Chaowasku, D.T. Ngo, H.T. Le. L. domatiophorusis, Paramignya trimera (Oliv.) Guillaum and Limnocitrus littoralis Swingle were completely ineffective against HSV viruses. ${ }^{26,27}$ Another research explored Mentha suaveolens essential oil effectiveness against HSV-1 replication in an in vitro model of infection. They found Mentha suaveolens essential oil could reduce HSV-1 replication with IC50 of $0.0051 \mathrm{mg} / \mathrm{mL}$ and $0.0014 \mathrm{mg} / \mathrm{mL}^{68}$

\section{Indole-Type Alkaloids}

Harmine (53) was isolated from Peganum harmala, Banisteriopsis caapi, and Passiflora incarnata. Compound 53 exhibited activity against $\mathrm{HSV}-2$ with an $\mathrm{IC}_{50}$ value of $0.1 \mu \mathrm{g} / \mathrm{mL}^{69}$ The combination of harmine with acyclovir showed a combination index of 0.5 , which indicated that these two compounds have a synergic effect. This suggests that harmine may be used with acyclovir to improve the treatment of genital herpes in immunocompromised 
patients. ${ }^{67}$ Harman (54) was isolated from Simira eleiezeriana and Simira glaziovii and was evaluated against HSV-1 and HSV-2. Harman showed good results with an $\mathrm{EC}_{50}$ value of $4.90 \mu \mathrm{M}$ and a SI of 11.8 for HSV-1, and an $\mathrm{EC}_{50}$ value of $71.8 \mu \mathrm{M}$ and SI of 24.7 for HSV-2. ${ }^{70}$ Vincosamide (55) and strictosamide (56) belong to a class of indole alkaloids and were isolated from the root bark of Nauclea latifolia Smith. Compounds 55 and 56 inhibited both acyclovir-sensitive and acyclovir-resistant HSV-2 strains. ${ }^{71}$ Manzamine A (57) was isolated from the sponges Pachypellina sp. and Haliclona sp. and had an anti-HSV-2 activity with a minimal effective concentration of $0.05 \mu \mathrm{g} / \mathrm{mL}^{72}$ 17-nor-Excelsinidine (58), an akuammigine-type alkaloid, was identified from A. scholaris. Compound $\mathbf{5 8}$ was tested against HSV in an HSV-transfected Vero cell line, and against adenovirus in an adenovirus-transfected HepG-2 cell line, and showed higher activity than acyclovir, with $\mathrm{EC}_{50}$ values of $6.97 \mu \mathrm{g} / \mathrm{mL}$ against $\mathrm{HSV}$ and $3.32 \mu \mathrm{g} / \mathrm{mL}$ against adenovirus. ${ }^{73}$

\section{Quinolone-Type Alkaloids}

Aaptamine (59) was isolated from the marine sponge Aaptos spptos collected in the waters of Malaysia. Compound 59 showed potential anti-HSV-1 activity with $71.4 \pm 0.4 \%$ protection from infection at $25 \mu \mathrm{g} / \mathrm{mL}$ with an $\mathrm{EC}_{50}$ value of 7.0 $\pm 0.1 \mu \mathrm{g} / \mathrm{mL}$, along with low cytotoxicity. ${ }^{74}$ 4-Methylaaptamine (60) was isolated from the marine sponge Aaptos sp. (collected in Abrolhos, Bahia, Brazil). Compound 60 had an anti-HSV activity with an $\mathrm{EC}_{50}$ value of $2.4 \mu \mathrm{M}$, which is more potent than acyclovir. ${ }^{75}$ Pumiloside (61) was isolated from the root bark of Nauclea latifolia Smith. Compound $\mathbf{6 1}$ inhibited both acyclovir-sensitive and acyclovir-resistant HSV-2 strains $^{71}$ (Figure 6).<smiles>COc1ccc2c(c1)[nH]c1c(C)nccc12</smiles>

53<smiles>Cc1nccc2c1[nH]c1ccccc12</smiles>

54<smiles>COc1cc2c(OC)c3c1C(=NC=C2)C=CN3</smiles>

59<smiles>COc1cc2ccnc3c2c(c1OC)N(C)C=C3</smiles>

60

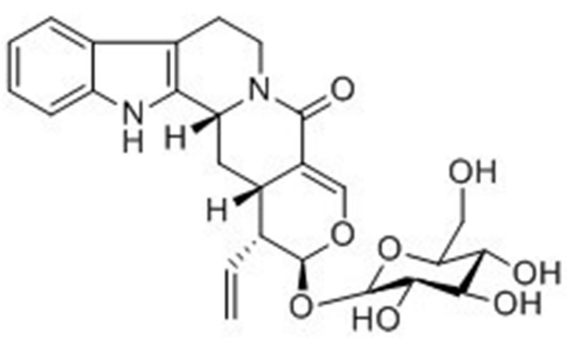

55

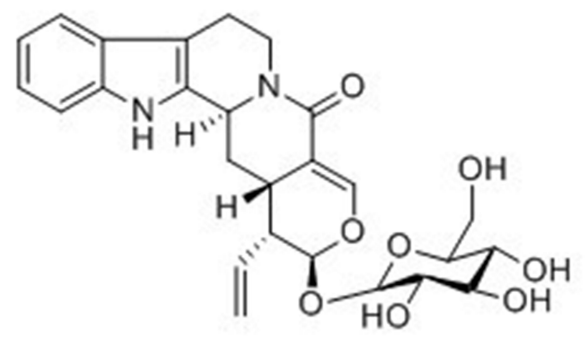

56

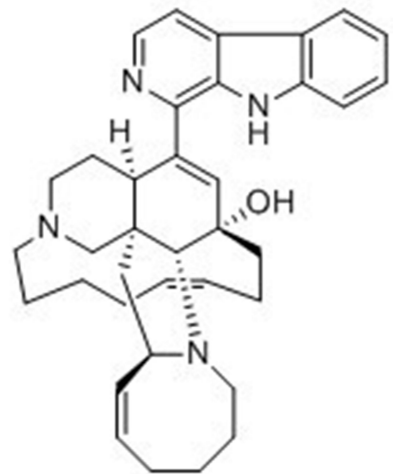

57

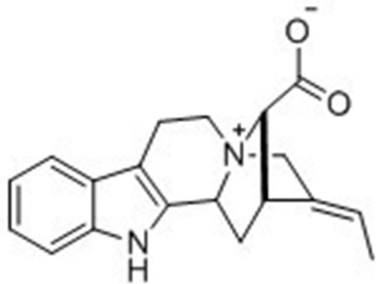

58<smiles>C=C[C@H]1C(OC2OC(CO)[C@@H](O)[C@H](O)[C@H]2O)OC=C2C(=O)N3CC4C5Nc6ccccc6C(=O)C5=CC4[C@@H]3C[C@@H]21</smiles>

61

Figure 6 Chemical structures of natural plant alkaloids with anti-herpes simplex virus properties. 


\section{An Isoquinoline-Type Alkaloid}

BBR (32) and the plants that contain this compound, including Coptidis rhizome and Ching-Wei-San, have all shown anti-HSV effects. BBR may interfere with the viral replication cycle sometime after virus penetration, and no later than the viral DNA synthesis step, and the activity was not affected by the preparation processes. ${ }^{75}$

\section{Extracts and Alkaloids from Plants with Anti-Dengue Virus Infection Activity}

Hirsutine (62), an indole alkaloid of Uncaria rhynchophylla, has been identified as a potent anti-dengue (DENV) compound exhibiting high efficacy and low cytotoxicity. Hirsutine showed antiviral activity against all DENV serotypes. Time-of-drug-addition and time-ofdrug-elimination assays indicated that hirsutine inhibited the viral particle assembly, budding, or release step but not the viral translation and replication steps in the DENV lifecycle. A subgenomic replicon system was used to confirm that hirsutine does not restrict viral genome RNA replication. Hirsutine is a DENV inhibitor and a potential candidate for treating dengue fever. ${ }^{76}$

The natural alkaloid anisomycin (63) was isolated from Streptomyces griseolus. At noncytotoxic concentrations, anisomycin strongly inhibited the replication of reference strains and clinical isolates of all DENV serotypes and Asian and African strains of ZIKV in Vero cells. Compound $\mathbf{6 3}$ is a potent and selective inhibitor of DENV and ZIKV in-vitro that impairs a post-entry step of viral replication, and low-dose anisomycin treatment provided some minimal benefit in a mouse model ${ }^{77}$ (Figure 7).

\section{Extracts and Alkaloids from Plants with Anti-Tobacco Mosaic Virus and Cucumber Mosaic Virus Infection Activity}

Two C19-diterpenoid alkaloids, hypaconitine (64) and mesaconitine (65), have been isolated from the ethanol extract of the root of Aconitum carmichaelii Debx. In an in-vitro antiviral activity test, compounds 64 and $\mathbf{6 5}$ had inactivation efficacy values of 82.4 and 85.6, respectively, against TMV at $500 \mu \mathrm{g} / \mathrm{mL}$. Compound $\mathbf{6 5}$ had an inactivation activity of $52.1 \%$ against $\mathrm{CMV}$ at $500 \mu \mathrm{g} / \mathrm{mL}$, which was almost equal to that of the commercial drug ningnanmycin. ${ }^{78}$

Phenanthroindolizidine alkaloids are a group of pentacyclic natural products isolated mainly from Cynanchum, Pergularia, and Tylophora species. Hypoestestain 1 (66) is a phenanthroindolizidine alkaloid that has exhibited cytotoxic activity, but its antiviral activity has not been investigated. A series of 13a-substituted hypoestestain analogs were designed to target TMV RNA. Compounds 67-72 exhibited good to excellent antiviral activities against TMV both in vitro and in vivo and had higher activity at 500 and $100 \mu \mathrm{g} / \mathrm{mL}$ than commercial ningnanmycin ${ }^{79}$ (Figure 7).

\section{Extracts and Alkaloids from Plants with Anti-Enterovirus 7I Infection Activity Matrine-Type Alkaloids}

Sophoridine (73) is one of the most abundant alkaloids in Sophora flavescens Aiton (Leguminosae). Compound $\mathbf{7 3}$ inhibited EV71 infection in Vero cells. Compound $\mathbf{7 3}$ was highly effective against EV71 when Vero cells were pretreated with Sophoridine for $2 \mathrm{~h}$. Sophoridine was highly effective at inhibiting EV71 attachment when Sophoridine concentrations were over $250 \mu \mathrm{g} / \mathrm{mL}^{80}$

\section{Piperazinedione-Type Alkaloids}

The alkaloid dimer (+)-pestaloxazine A (74), with an unprecedented symmetric spiro-[oxazinane-

piperazinedione] skeleton consisting of 22 carbons and 12 heteroatoms, was isolated from a Pestalotiopsis sp. fungus derived from a soft coral. Compound $\mathbf{6 8}$ exhibited potent antiviral activity against EV71 with an $\mathrm{IC}_{50}$ value of 14.2 $\pm 1.3 \mu \mathrm{M}$, which was stronger than that of the positive control ribavirin $^{81}$ (Figure 7).

\section{Extracts and Alkaloids from Plants with Anti-Coxsackievirus $\mathrm{B}_{3}\left(\mathrm{CVB}_{3}\right)$ Infection Activity Extracts}

The antiviral effect of an ethanol extract of the roots and rhizomes of Rheum palmatum (Polygonaceae family) against coxsackievirus $\mathrm{B}_{3}\left(\mathrm{CVB}_{3}\right)$ was evaluated in tissue culture cells and a mouse model. The ethanol extract from R. palmatum showed significant inhibitory activity against $\mathrm{CVB}_{3}$-infected HEP-2 cells when added after infection. The serum of mice still contained the pharmaceutical compound $24 \mathrm{~h}$ after intraperitoneal injection, and the extract exhibited an antiviral effect on $\mathrm{CVB}_{3}$-infected cells. The ethanol extract-treated mice showed alleviated clinical signs, a better survival rate, and a higher maximum tolerated dose along with decreased viral titers compared with the virus control group. These results indicated that the ethanol extract from $R$. palmatum had anti$\mathrm{CVB}_{3}$ activity in vitro and in vivo ${ }^{82}$ (Table 1 ). 
<smiles>CC[C@H]1CN2CCc3c([nH]c4ccccc34)[C@H]2C[C@H]1/C(=C\OC)C(=O)OC</smiles>

62

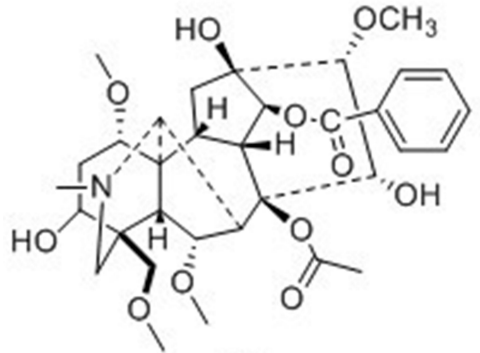

65<smiles>COc1ccc(C[C@@H]2NC[C@@H](O)[C@H]2OC(C)=O)cc1</smiles>

63<smiles>COc1ccc2c3c(c4cc(OC)c(OC)cc4c2c1)CC1(C)CCCN3C1</smiles>

66

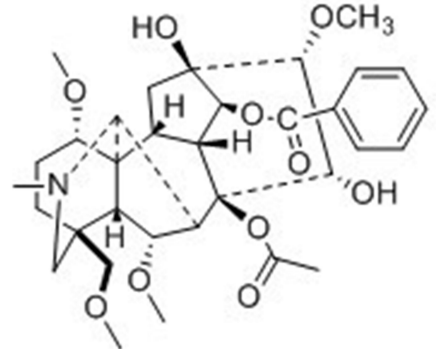

64<smiles>COc1ccc2c3c(c4cc(OC)c(OC)cc4c2c1)CC1(CO)CCCN1C3</smiles>

67

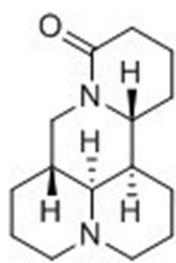

73<smiles>COc1ccc2c3c(c4cc(OC)c(OC)cc4c2c1)CC1(COC(=O)c2ccccc2)CCCN1C3</smiles>

68<smiles>COc1ccc2c3c(c4cc(OC)c(OC)cc4c2c1)CC1(C(=O)NN)CCCN3C1</smiles>

69<smiles>COc1ccc2c3c(c4cc(OC)c(OC)cc4c2c1)CC1(C=O)CCCN3C1</smiles>

70<smiles></smiles>

75

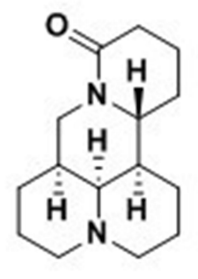

76<smiles>COc1ccc2c3c(c4cc(OC)c(OC)cc4c2c1)CC1(C(=N)O)CCCN3C1</smiles>

71<smiles>COc1cc2c3c(c4cc(OC)c(OC)cc4c2cc1OC)CC1(C(=N)O)CCCN1C3</smiles>

72<smiles>C/C(=C\C(=O)N1CCC[C@]2(NC(=O)[C@@]3(CCCN(C(=O)/C=C(\C)CCO)O3)NC2=O)O1)CCO</smiles>

74

Figure 7 Chemical structures of natural plant alkaloids with other antiviral properties.

Indole-Type Alkaloids

Isatibisindosulfonic acid B (37) and isatindosulfonic acid B (38) showed antiviral activities against coxsackievirus B3 [50]. Isatindigobisindoloside B (39), isatindigobisindoloside $\mathrm{E}$ (40), and isatindigobisindoloside $\mathrm{F}$ (41) also showed antiviral activities against coxsackievirus B3 [51].

\section{Matrine-Type Alkaloids}

The matrine-type alkaloid (-)-12ß-hydroxyoxysophocarpine (75) was isolated from the rhizomes of Sophora tonkinensis. Alkaloid $\mathbf{7 5}$ exhibited antiviral activity against coxsackievirus $\mathrm{B} 3$ with an $\mathrm{IC}_{50}$ value of $26.62 \mu \mathrm{M}^{83}$ (Figure 7). 


\section{Extracts and Alkaloids from Plants with Anti-Measles Virus Infection Activity}

Cajanus cajan (Leguminosae family), a tropical shrub, is a source of food and traditional medicines, and aqueous and ethanol extracts of Cajanus cajan have been evaluated for activity against the measles virus. An antivirus assay showed that a hot-water extract of Cajanus cajan had high activity against the measles virus ${ }^{84}$ (Figure 7).

\section{Extracts and Alkaloids from Plants with Anti-Porcine Reproductive Respiratory Syndrome Virus and Porcine Circovirus Type 2 Infection Activity}

Matrine (76) is an alkaloid extracted from Sophora flavescens Ait. Matrine exhibited antiviral activity against PRRSV/PCV2 co-infection in PAM cells in vitro. The underlying antiviral mechanism of matrine may be mediated through its ability to partly regulate the TLR3,4/NF-кB/TNF- $\alpha$ pathway ${ }^{85}$ (Figure 7).

\section{Extracts and Alkaloids from Plants with Anti-Chikungunya Virus Activity}

BBR (32) $\left(\mathrm{EC}_{50}=1.8 \mu \mathrm{M}\right)$ is a plant-derived isoquinoline alkaloid that inhibited CHIKV replication in a dosedependent manner and had broad antiviral activity against two other alphaviruses, Semliki Forest virus and Sindbis virus. ${ }^{86}$

\section{Extracts and Alkaloids from Plants with Anti-Inflammatory Effects}

Many viral infections, such as influenza virus infections, are characterized by an excessive inflammatory response, and the viral load does not correlate with the worsening of symptoms. Much research on infectious diseases has focused on removing the pathogens using antimicrobial drugs. Immunological complications, such as a cytokine storm can occur, and thus antiviral treatment alone is not enough and should be combined with appropriate antiinflammatory agents.

Inflammation is a defense system that removes deleterious stimuli or microbial infections. When the inflammatory responses are initiated, damaged tissue is rapidly repaired by eliciting the appropriate signals. ${ }^{87}$ Inflammation has relevance to numerous diseases, including viral diseases, rheumatoid arthritis, chronic bronchitis, asthma, and cancer. ${ }^{88,89}$ Many members of the TLR family are involved in controlling the inflammatory response. After TLR activation, they are dimerized or collaborate with other receptors at the cell surface..$^{90}$ The myeloid differentiation primary response 88 (MyD88) gene is the most generally used TLR adaptor. The MyD88-dependent pathway initiates the formation of a cytoplasmic Tollinterleukin-1 receptor (TIR) domain. MyD88 is recruited through TIR domain interaction, promoting the recruitment of IL-1 receptor-associated kinase 4 (IRAK-4) (the death domain of IRAK-4 interacts with the death domain of MyD88) and the phosphorylation of IRAK-1. These enzymes induce the activation of the inhibitory $\kappa \mathrm{B}$ (І $\kappa \mathrm{B}$ ) kinase complex. Phosphorylated I $\mathrm{KB}$ undergoes proteasomal degradation, which in turn activates NF- $\kappa B$. The released NF- $\kappa \mathrm{B}$ translocates to the nucleus and binds DNA, regulating the expression of a wide range of genes encoding inflammatory cytokines, such as TNF $\alpha$ and interleukin-6 (IL-6) ${ }^{91}$ (Figure 9). Many natural alkaloids have been shown to regulate the NF-кB signaling pathway. Inflammation alters the expression of several cellular genes and a cellular signaling network, including MAPK and JAK-STAT signaling pathways, occurs during inflammation.

In particular, the influenza viruses initiate host cellular and molecular immune mechanisms. Th1/Th2 cells are usually considered to start the cell immune response. It has been demonstrated that the secretion of inflammatory cytokines, type I interferon (IFN), chemokines, and antimicrobial peptides are intimately involved in the Th1/Th2 balance and immune response. ${ }^{92}$ Here, we summarize recent findings of the use of alkaloids to treat lung infections involving anti-inflammatory or innate immune responses (Figure 8).

\section{A Pyridine Alkaloid}

Nicotine (80) reduced NF- $\mathrm{kB}$-mediated transcription as measured by IL-2 and I $\kappa$ transcription. ${ }^{93}$ The $\alpha 7 \mathrm{nAChR}$ plays a major role in the anti-inflammatory effects of nicotine, and nicotine attenuates inflammation in both obesity and ulcerative colitis. The anti-inflammatory effects of nicotine may be mediated via the expression of several nAChRs on a particular target cell. Selective $\alpha 7 \mathrm{nAChR}$ agonists may be a potential new class of antiinflammatory drugs. ${ }^{94}$

\section{A Quinolone Alkaloid}

The quinolone alkaloid orixalone A (81) from Orixa japonica strongly inhibited NO production in murine 
<smiles>C[C@H]([C@H](O)c1ccccc1)N(C)C</smiles>

77<smiles>COc1c(CC(=O)C(C)C)c(=O)n(C)c2c(OC)cccc12</smiles>

81<smiles>COC1=C[C@H]2[C@H]3Cc4ccc(OC)c(O)c4[C@@]2(CC1=O)CN3C</smiles>

84<smiles>COc1ccc2c(OC)c3ccoc3nc2c1OC</smiles>

87<smiles>CN[C@H](C)[C@H](O)c1ccccc1</smiles>

78<smiles>CN[C@H](C)[C@H](O)c1ccccc1</smiles>

79<smiles>CN1CCCC1c1cccnc1</smiles>

80<smiles>COc1cc2c(c(OC)c1OC)-c1ccc(OC)c(=O)cc1C(NC(C)=O)CC2</smiles>

82<smiles>O=c1c2ccccc2nc2c3[nH]c4ccccc4c3ccn12</smiles>

85<smiles>COc1ccc2c(cnc3c4cc5c(cc4ccc23)OCO5)c1OC</smiles>

88<smiles>COc1ccc2c3c(c4cc(OC)c(OC)cc4c2c1)CC1CCCN1C3</smiles>

83<smiles>CN1c2ccccc2C(=O)N2CCc3c([nH]c4ccccc34)C21</smiles>

86

Figure 8 Chemical structures of natural plant alkaloids with anti-inflammatory activities.

macrophage RAW 264.7 cells stimulated with interferon- $\gamma$ and LPS at micromolar concentrations and, thus, might be used as an anti-inflammatory or cancer-preventive agent to suppress the excessive synthesis of NO. ${ }^{95}$

\section{An Isoquinoline-Type Alkaloid}

Anti-inflammatory activity of BBR (32) has been indicated by the reduction of proinflammatory cytokines, including TNF- $\alpha$, IL-13, IL-6, IL-8, and IFN- $\gamma$. In cell models, BBR was able to completely antagonize the TNF- $\alpha$-mediated barrier defects, which are related to tyrosine kinase, and the pAkt and NF-kB pathways. ${ }^{11}$ BBR significantly inhibited the binding of NF- $\mathrm{KB}$ and AP-1 at concentrations of 4-10 M or higher. BBR also inhibited LPS-induced MCP-
1/CCL2 production in vitro via AP-1 and NF$\mathrm{KB}$-dependent pathways. ${ }^{61,96-99}$ It has been reported that BBR repressed proinflammatory responses through AMPactivated protein kinase activation in macrophages, significantly down-regulating the expression of proinflammatory genes, such as TNF- $\alpha$, IL- $1 \beta$, IL- 6 , monocyte chemoattractant protein-1 (MCP-1), inducible nitric oxide synthase (iNOS), and cyclooxygenase-2 (COX-2).

BBR (32), a natural isoquinoline alkaloid isolated from the berberis species, has a wide array of biological properties, such as anti-inflammatory, antibacterial, antifungal, and antihelminthic effects. BBR relieved pulmonary inflammation, and reduced necrosis, inflammatory cell infiltration, and pulmonary edema, induced by a viral 


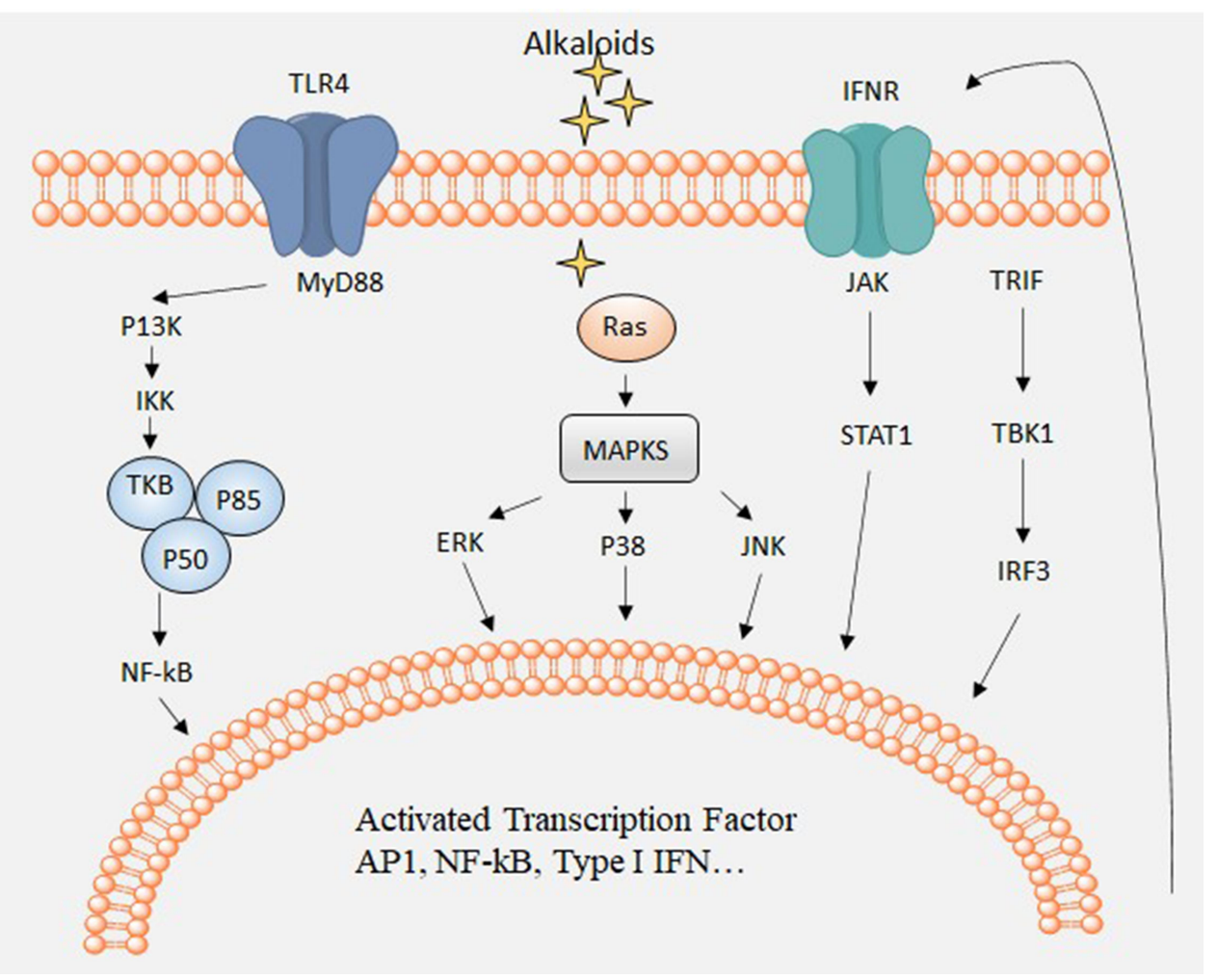

Figure 9 Major cell signaling pathways related to inflammation.

infection in mice when compared with vehicle-treated mice. BBR suppressed the viral infection-induced up-regulation of components of the TLR7 signaling pathway,

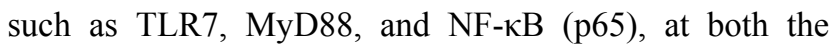
mRNA and protein levels. Furthermore, BBR significantly inhibited the viral infection-induced increases in the Th1/ Th2 and Th17/Treg ratios, as well as the production of inflammatory cytokines. ${ }^{49}$

BBR inhibited EV71 replication by downregulating autophagy and the MEK/ERK signaling pathway. These findings suggested that BBR may be a potential agent or supplement against EV71 infection. ${ }^{100}$

BBR reduces virus replication and targets specific interactions between the virus and its host. BBR inhibits the replication of HSV, human cytomegalovirus, human papillomavirus, and HIV. This alkaloid has the ability to regulate the MEK-ERK, AMP-activated protein kinase/mTOR, and NF$\kappa \mathrm{B}$ signaling pathways, which are necessary for viral replication. Furthermore, it has been reported that BBR can support the host immune response leading to viral clearance. ${ }^{100}$

\section{Amine Alkaloids}

Colchicine (82) is a widely available, inexpensive drug with a range of anti-inflammatory properties. Colchicine affects the assembly of the NLRP3 inflammasome, thereby reducing the release of IL-1 $\beta$ and other interleukins, including IL-6, that are formed in response to danger signals. In endothelial cells, colchicine inhibits the production of IL$1 \beta$ and the expression of E-selectin required for neutrophil adhesion. ${ }^{101}$ Colchicine can limit the extent of inflammatory injury by promoting anti-inflammatory macrophages to release IL-10, TGF- $\beta$, and other anti-inflammatory cytokines that act to suppress proinflammatory signaling and promote favorable healing by dampening the growth of vascular smooth muscle cells. ${ }^{9}$

The potential antiviral mechanisms of compounds from Ephedra sinica Stapf have been investigated. L-Methylephedrin (LMEP, 77), L-ephedrine (LEP, 78), and D-pseudo-ephedrine (DPEP, 79) significantly inhibited the proliferation of influenza A virus in vitro. These compounds also significantly inhibited the mRNA expression levels of related genes in the TLR3, TLR4, and TLR7 signaling pathways, which was accompanied by the down-regulation of TNF- $\alpha$ levels and the upregulation of IFN- $\beta$ levels in the cell supernatant. Animal research further indicated, at the 3rd and 7th days after infection, that LEP and DPEP significantly attenuated lung injury, decreased the lung index, the 
virus load in the lung, and the level of IL- $1 \beta$ in serum, inhibited the mRNA expression levels of TNF- $\alpha$, TLR3, TLR4, TLR7, MyD88, NF-kB p65, and RIG-1, as well as the protein expression levels of TLR4, TLR7, MyD88, and NF- $\mathrm{kB}$ p65, and markedly increased the thymus index, the level of IL-10 in serum, and the mRNA expression level of IFN- ${ }^{10}{ }^{10}$

\section{An Indolizidine Alkaloid}

Antofine (83) is a phenanthroindolizidine alkaloid isolated from the root of Cynanchum paniculatum Kitagawa (Asclepiadaceae) that is used as a herbal remedy. ${ }^{102}$ Chou et al recently reported that antofine may not only inhibit endotoxin-stimulated inflammation but also modulate cellular metabolism via an AMP-activated protein kinase. ${ }^{103}$

\section{A Isoquinoline Alkaloid}

Sinomenine (84) is a morphine-type alkaloid isolated from the Chinese herb Caulis Sinomenii. Sinomenine is one of the most widely known alkaloids owing to its various therapeutic properties, including anti-inflammatory and immunosuppressive activities. ${ }^{104}$

\section{Indolopyridoquinazolinone Alkaloids}

Two indolopyridoquinazolinone alkaloids, rutaecarpine (85) and evodiamine (86), as well as the structurally related quinazoline-2,4-dione, goshuyuamide II, were evaluated for their anti-inflammatory activities. These compounds strongly inhibited PGE2 synthesis in LPStreated RAW 264.7 cells at $1-10 \mu \mathrm{M}$, and evodiamine also inhibited cyclooxygenase-2 (COX-2) induction and NF- $\mathrm{KB}$ activation. ${ }^{105}$

\section{A Quinolinone Alkaloid}

Ruta graveolens L. (Rutaceae), commonly known as rue, has been reported to have medicinal properties against aching pain, eye problems, rheumatism, and dermatitis. ${ }^{106}$ Skimmianine (87), isolated from $R$. graveolens L., was injected into mice $(5.0 \mathrm{mg} / \mathrm{kg})$ and found to alleviate carrageenan-induced acute inflammation, decrease the mRNA levels of TNF- $\alpha$ and IL- 6 , and reduce PGE2 and NO levels, COX-2 and 5-lipoxygenase activities, neutrophil infiltration, lipid peroxidation, and associated oxidative stress in the paw tissue. $^{71}$

\section{A Phenanthridine Alkaloid}

Zanthoxylum schinifolium is an aromatic shrub, the pericarp and leaves of which are widely used in culinary applications in East Asian countries. Norchelerythrine (88) and nornitidine (89) from Zanthoxylum schinifolium exhibited significant inhibition of NF- $\mathrm{KB}$ activation in a dose-dependent manner. Furthermore, these compounds inhibited TNF- $\alpha$-induced expression of inducible nitric oxide synthase (iNOS) and intercellular adhesion molecule-1 mRNA, and dose-dependent inhibition of iNOS promoter activity. ${ }^{107}$

\section{A Matrine-Type Alkaloid}

Oxymatrine (15) is a major active compound of Sophora root. ${ }^{108}$ Oxymatrine had excellent anti-influenza A virus activity against eight strains in vitro. Oxymatrine significantly decreased the promoter activities of the TLR3, TLR4, TLR7, MyD88, and TRAF6 genes, inhibited virusinduced activation of the Akt, ERK1/2, p38 MAPK, and NF$\kappa B$ pathways, and suppressed the expression of inflammatory cytokines and MMP-2/9. Activators of the TLR4, p38 MAPK, and NF- $\mathrm{BB}$ pathways significantly antagonized the anti-influenza activity of oxymatrine in vitro, including virus replication and virus-induced cytopathogenic effects. ${ }^{109}$

\section{A Pyrrole-Type Alkaloid}

Epigoitrin (46), a natural alkaloid from Isatis indigotica, provides protection against influenza infection by reducing the host's susceptibility to the influenza virus under stress. Epigoitrin significantly decreased the susceptibility of mice to an influenza virus as evidenced by lower mortality, attenuated inflammation, and decreased viral replication in the lungs. In addition, epigoitrin reduced the protein expression of mitofusin-2, which elevated mitochondria antiviral signaling protein expression and subsequently increased the production of IFN- $\beta$ and interferon-inducible transmembrane 3, thereby helping to fight viral infections. This study indicated that epigoitrin reduced the susceptibility to the influenza virus via mitochondrial antiviral signaling. ${ }^{57}$

\section{Conclusions and Perspectives}

Alkaloids have attracted considerable attention from researchers worldwide since the study of alkaloids began in 1803 when nicotine was discovered. Alkaloids represent a promising and expanding platform for the development of active natural compounds as new pharmaceuticals. The molecular structures of alkaloids provide valuable leads for antiviral drug design. Isoquinoline (BBR, 32) alkaloids exhibit broad-spectrum antiviral activity, including activity against HIV, HCV, IFV, HSV and may also reduce related anti-inflammatory activities. Quinoline alkaloid 
compounds have provided a new route for drug development via the treatment of both HIV and HCV infections. The discovery of aloperine (1), a quinolizidine-type lead compound, which functions by virus-induced cell-cell fusion, has provided a route to develop drugs that target both HIV and HCV infections. In addition to the activities mentioned herein, alkaloids exhibit other important bioactivities, including antifungal, antiparasitic, insecticidal, and antiplatelet activities. We hope that such alkaloids will provide more avenues for the development of new drugs in the future through targeted pharmacological viral infected host modeling and the resulting synthetic modifications.

Viral infections are a worldwide public health problem that affects a large proportion of the world's population. Medicinal plants or herbs have been widely used to treat various infectious diseases for thousands of years. Literature reviews have demonstrated that plants are therapeutically effective for treating viral diseases. Medicinal plants and herbs are recognized as a rich source of therapeutic agents for the management of viral disorders. The active constituents of plants, such as alkaloids, have been reported to have antiviral activity. Such compounds can function by interacting with different viral protein receptors and have been shown to play an important role in the management of viruses and the inflammatory response in host models. Although the contribution of modern synthetic medicine for elevating human suffering cannot be underestimated, the fact that synthetic drugs exert serious side effects cannot be ignored. In the future, more scientific studies are needed to develop alkaloidal compounds as antiviral therapeutic agents and potential regulators of the host immune response.

\section{Acknowledgments}

This work was supported by grants from the National Natural Science Foundation of China (NO. 81873071) and the Pearl River S\&T Nova Program of Guangzhou (NO. 201906010059).

\section{Disclosure}

The authors report no conflicts of interest for this work.

\section{References}

1. Vahidnia F, Stramer SL, Kessler D, et al. Recent viral infection in US blood donors and health-related quality of life (HRQOL). Qual Life Res. 2017;26:349-357. doi:10.1007/s11136-016-1392-5

2. Nichol KL. The efficacy, effectiveness and cost-effectiveness of inactivated influenza virus vaccines. Vaccine. 2003;21:17 69-1775. doi:10.1016/s0264-410x(03)00070-7
3. Martinez FJ. Pathogen-directed therapy in acute exacerbations of chronic obstructive pulmonary disease. Proc Am Thorac Soc. 2007;4:647-658. doi:10.1513/pats.200707-097TH

4. Cho YK, Kim JE. Effect of Korean Red Ginseng intake on the survival duration of human immunodeficiency virus type 1 patients. J Ginseng Res. 2017;41:222-226. doi:10.1016/j.jgr.20 16.12.006

5. Gurib-Fakim A. Medicinal plants: traditions of yesterday and drugs of tomorrow. Mol Aspects Med. 2006;27:1-93. doi:10.10 16/j.mam.2005.07.008

6. Moghadamtousi SZ, Nikzad S, Kadir HA, Abubakar S, Zandi K. Potential antiviral agents from marine fungi: an overview. Mar Drugs. 2015;13:4520-4538. doi:10.3390/md13074520

7. Newman DJ, Cragg GM. Natural products as sources of new drugs over the nearly four decades from $01 / 1981$ to $09 / 2019$. J Nat Prod. 2020;83:770-803. doi:10.1021/acs.jnatprod.9b01285

8. Gupta MK, Sharma PK. A Text Book of Pharmacognosy. 3rd ed. Meerut: Pragati Prakashan; 2014.

9. Bauriedel G, Ganesh S, Uberfuhr P, Welsch U, Höfling B. [Growth-inhibiting effect of colchicine on cultured vascular wall myocytes from arteriosclerotic lesions]. Z Kardiol. 1992;81: 92-98. German.

10. Wei W, Du H, Shao C, et al. Screening of antiviral components of Ma Huang Tang and investigation on the ephedra alkaloids efficacy on influenza virus type A. Front Pharmacol. 2019;10:961. doi:10.3389/fphar.2019.00961

11. Amasheh M, Fromm A, Krug SM, et al. TNFalpha-induced and berberine-antagonized tight junction barrier impairment via tyrosine kinase, Akt and NFkappaB signaling. $J$ Cell Sci. 2010;123:4145-4155. doi:10.1242/jcs.070896

12. Rutherford GW, Anglemyer A, Easterbrook PJ, et al. Predicting treatment failure in adults and children on antiretroviral therapy. Aids. 2014;28:S161-S169. doi:10.1097/QAD.0000000000000236

13. Gujjeti R, Namthabad S, Mamidala E. HIV-1 reverse transcriptase inhibitory activity of Aerva lanata plant extracts. BMC Infect Dis. 2014;14:1-11. doi:10.1186/1471-2334-14-S3-P12

14. Monera-Penduka TG, Maponga CC, Wolfe AR, Wiesner L, Morse GD, Nhachi CF. Effect of Moringa oleifera Lam. leaf powder on the pharmacokinetics of nevirapine in HIV-infected adults: a one sequence cross-over study. AIDS Res Ther. 2017;14:12. doi:10.1186/s12981-017-0140-4

15. Nworu CS, Okoye EL, Ezeifeka GO, et al. Extracts of Moringa oleifera Lam. showing inhibitory activity against early steps in the infectivity of HIV-1 lentiviral particles in a viral vector-based screening. Afr J Biotechnol. 2013;12:4866-4873. doi:10.5897/ AJB2013.12343

16. Nutan N, Modi M, Dezzutti,CS, et al. Extracts from Acacia catechu suppress HIV-1 replication by inhibiting the activities of the viral protease and Tat. Virol J. 2013;10:309. doi:10.1186/ 1743-422x-10-309

17. Estari M, Venkanna L, Sripriya D, Lalitha R. Human immunodeficiency virus (HIV-1) reverse transcriptase inhibitory activity of Phyllanthus emblica plant extract. Biol Med. 2012;4:178-182.

18. Wilson D, Goggin K, Williams K, et al. Consumption of Sutherlandia frutescens by HIV-seropositive South African Adults: an adaptive double-blind randomized placebo controlled trial. PLoS One. 2015;10:e0128522. doi:10.1371/journal.pone.0128522

19. Zhang X, Yang LM, Liu GM, et al. Potent anti-HIV activities and mechanisms of action of a pine cone extract from Pinus yunnanensis. Molecules. 2012;17:6916-6929. doi:10.3390/ molecules 17066916

20. Louvel S, Moodley N, Seibert I, et al. Identification of compounds from the plant species Alepidea amatymbica active against HIV. S Afr J Bot. 2013;86:9-14. doi:10.1016/j.sajb.20 13.01.009 
21. Kapewangolo P, Hussein AA, Meyer D. Inhibition of HIV-1 enzymes, antioxidant and anti-inflammatory activities of Plectranthus barbatus. J Ethnopharmacol. 2013;149:184-190. doi:10.1016/j.jep.2013.06.019

22. Liang J, Chen J, Tan Z, et al. Extracts of the medicinal herb Sanguisorba officinalis inhibit the entry of human immunodeficiency virus-1. J Food Drug Anal. 2013;21:S52-S58. doi:10.10 16/j.jfda.2013.09.034

23. Xiao WL, Wang RR, Zhao W, et al. Anti-HIV-1 activity of lignans from the fruits of Schisandra rubriflora. Arch Pharm Res. 2010;33:697-701. doi:10.1007/s12272-010-0508-7

24. Xu L, Grandi N, Del Vecchio C, et al. From the traditional Chinese medicine plant Schisandra chinensis new scaffolds effective on HIV-1 reverse transcriptase resistant to non-nucleoside inhibitors. J Microbiol. 2015;53:288-293. doi:10.1007/s12275015-4652-0

25. Zhang YB, Luo D, Yang L, et al. Matrine-Type Alkaloids from the Roots of Sophora flavescens and Their Antiviral Activities against the Hepatitis B Virus. J Nat Prod. 2018;81:2259-2265. doi:10.1021/acs.jnatprod.8b00576

26. Le NT, Ho DV, Doan TQ, et al. In vitro antimicrobial activity of essential oil extracted from leaves of Leoheo domatiophorus Chaowasku, D.T. Ngo and H.T. Le in Vietnam. Plants. 2020;9:453-467. doi:10.3390/plants9040453

27. Le NT, Ho DV, Doan TQ, et al. Biological activities of essential oils from leaves of Paramignya trimera (Oliv.) Guillaum and Limnocitrus littoralis (Miq.) Swingle. Antibiotics. 2020;9:20 7-219. doi:10.3390/antibiotics9040207

28. Le NT, Donadu MG, Ho DV, et al. Biological activities of essential oil extracted from leaves of Atalantia sessiflora Guillauminin Vietnam. J Infect Dev Ctries. 2020;14:1054-1064. doi: $10.3855 /$ jidc. 12469

29. Dang Z, Zhu L, Lai W, et al. Aloperine and its derivatives as a new class of HIV-1 entry inhibitors. ACS Med Chem Lett. 2016;7:240-244. doi:10.1021/acsmedchemlett.5b00339

30. Chaves Valadão AL, Abreu CM, Dias JZ, et al. Natural plant alkaloid (Emetine) inhibits HIV-1 replication by interfering with reverse transcriptase activity. Molecules. 2015;20:11474-11489. doi:10.3390/molecules200611474

31. Wang YS, Wen ZQ, Li BT, Zhang HB, Yang JH. Ethnobotany, phytochemistry, and pharmacology of the genus Litsea: an update. $J \quad$ Ethnopharmacol. 2016;181:66-107. doi:10.1016/j. jep.2016.01.032

32. Custódio DL, da Veiga Junior VF. Lauraceae alkaloids. RSC Adv 2014;4:21864. doi:10.1039/C4RA01904K

33. Ahmed N, Brahmbhatt KG, Sabde S, Mitra D, Singh IP, Bhutani KK. Synthesis and anti-HIV activity of alkylated quinoline 2,4-diols. Bioorg Med Chem. 2010;18:2872-2879. doi:10.1016/j.bmc.2010.03.015

34. Jadulco RC, Pond CD, Van Wagoner RM, et al. 4-Quinolone alkaloids from Melochia odorata. J Nat Prod. 2014;77:183-187. doi:10.1021/np400847t

35. Zhang BM, Wang ZB, Xin $\mathrm{P}$, Wang $\mathrm{QH}, \mathrm{Bu} \mathrm{H}$, Kuang HX. Phytochemistry and pharmacology of genus Ephedra. Chin J Nat Med. 2018;16:811-828. doi:10.1016/s1875-5364(18)30123-7

36. Zhang YB, Zhan LQ, Li GQ, et al. Dimeric matrine-type alkaloids from the roots of Sophora flavescens and their anti-hepatitis B virus activities. J Org Chem. 2016;81:6273-6280. doi:10.1021/ acs.joc.6b00804

37. Zhang YB, Zhang XL, Chen NH, et al. Four matrine-based alkaloids with antiviral activities against HBV from the seeds of Sophora alopecuroides. Org Lett. 2017;19:424-427. doi:10.1021/ acs.orglett.6b03685

38. Chou SC, Huang TJ, Lin EH, Huang CH, Chou CH. Antihepatitis B virus constituents of Solanum erianthum. Nat Prod Commun. 2012;7:153-156. doi:10.1177/1934578X1200700205
39. Rehman S, Ashfaq UA, Riaz S, Javed T, Riazuddin S. Antiviral activity of Acacia nilotica against hepatitis $\mathrm{C}$ virus in liver infected cells. Virol J. 2011;8:220. doi:10.1186/1743-422x-8-220

40. Wahyuni TS, Widyawaruyanti A, Lusida MI, et al. Inhibition of hepatitis C virus replication by chalepin and pseudane IX isolated from Ruta angustifolia leaves. Fitoterapia. 2014;99:276-283. doi:10.1016/j.fitote.2014.10.011

41. Cao MM, Zhang Y, Li XH, et al. Cyclohexane-fused octahydroquinolizine alkaloids from myrioneuron faberi with activity against hepatitis C virus. J Organ Chem. 2014;79:7945-7950. doi:10.1021/jo501076x

42. Zhang X, Lv XQ, Tang S, et al. Discovery and evolution of aloperine derivatives as a new family of HCV inhibitors with novel mechanism. Eur J Med Chem. 2018;143:1053-1065. doi:10.1016/j.ejmech.2017.12.002

43. Hung TC, Jassey A, Liu CH, et al. Berberine inhibits hepatitis $\mathrm{C}$ virus entry by targeting the viral E2 glycoprotein. Phytomedicine. 2019;53:62-69. doi:10.1016/j.phymed.2018.09.025

44. Peng ZG, Fan B, Du NN, et al. Small molecular compounds that inhibit hepatitis $\mathrm{C}$ virus replication through destabilizing heat shock cognate 70 messenger RNA. Hepatology. 2010;52: 845-853. doi:10.1002/hep.23766

45. Kinoshita E, Hayashi K, Katayama H, Hayashi T, Obata A. Antiinfluenza virus effects of elderberry juice and its fractions. Biosci Biotechnol Biochem. 2012;76:1633-1638. doi:10.1271/bbb.12 0112

46. Ho GT, Ahmed A, Zou YF, Aslaksen T, Wangensteen H, Barsett H. Structure-activity relationship of immunomodulating pectins from elderberries. Carbohydr Polym. 2015;125:314-322. doi:10.1016/j.carbpol.2015.02.057

47. Porter RS, Bode RF. A review of the antiviral properties of black elder (Sambucus nigra L.) products. Phytother Res. 2017;31: 533-554. doi:10.1002/ptr.5782

48. Ho GT, Zou YF, Aslaksen TH, Wangensteen H, Barsett H. Structural characterization of bioactive pectic polysaccharides from elderflowers (Sambuci flos). Carbohydr Polym. 2016;13 5:128-137. doi:10.1016/j.carbpol.2015.08.056

49. Yan YQ, Fu YJ, Wu S, et al. Anti-influenza activity of berberine improves prognosis by reducing viral replication in mice. Phytother Res. 2018;32:2560-2567. doi:10.1002/ptr.6196

50. Wu Y, Li JQ, Kim YJ, Wu J, Wang Q, Hao Y. In vivo and in vitro antiviral effects of berberine on influenza virus. Chin J Integr Med. 2011;17:444-452. doi:10.1007/s11655-011-0640-3

51. Lee IK, Hwang BS, Kim DW, et al. Characterization of neuraminidase inhibitors in Korean papaver rhoeas bee pollen contributing to anti-influenza activities in vitro. Planta Med. 2016;82: 524-529. doi:10.1055/s-0041-111631

52. Shi D, Chen M, Liu L, et al. Anti-influenza A virus mechanism of three representative compounds from Flos Trollii via TLRs signaling pathways. $J$ Ethnopharmacol. 2020;253:112634. doi:10. 1016/j.jep.2020.112634

53. Meng L, Guo Q, Liu Y, et al. Indole alkaloid sulfonic acids from an aqueous extract of Isatis indigotica roots and their antiviral activity. Acta pharmaceutica Sinica B. 2017;7:334-341. doi:10.10 16/j.apsb.2017.04.003

54. Liu YF, Chen MH, Guo QL, et al. Antiviral glycosidic bisindole alkaloids from the roots of Isatis indigotica. J Asian Nat Prod Res. 2015;17:689-704. doi:10.1080/10286020.2015.1055729

55. Peng J, Lin T, Wang W, et al. Antiviral alkaloids produced by the mangrove-derived fungus Cladosporium sp. PJX-41. J Nat Prod. 2013;76:1133-1140. doi:10.1021/np400200k

56. Ping $\mathrm{X}$, Weiyang $\mathrm{Y}$, Jianwei $\mathrm{C}$, et al. Antiviral activities against influenza virus (FM1) of bioactive fractions and representative compounds extracted from Banlangen (Radix Isatidis). J Tradit Chin Med. 2016;36:369-376. doi:10.1016/S0254-6272(16) 30051-6 
57. Luo Z, Liu LF, Wang XH, et al. Epigoitrin, an alkaloid from isatis indigotica, reduces $\mathrm{H} 1 \mathrm{~N} 1$ infection in stress-induced susceptible model in vivo and in vitro. Front Pharmacol. 2019;10:78. doi:10.3389/fphar.2019.00078

58. Li R, Liu T, Liu M, Chen F, Liu S, Yang J. Anti-influenza A virus activity of dendrobine and its mechanism of action. J Agric Food Chem. 2017;65:3665-3674. doi:10.1021/acs.jafc.7b00276

59. Yang L, Zhang YB, Zhuang L, et al. Diterpenoid alkaloids from delphinium ajacis and their anti-RSV activities. Planta Med. 2017;83:111-116. doi:10.1055/s-0042-107252

60. Bag P, Chattopadhyay D, Mukherjee H, et al. Anti-herpes virus activities of bioactive fraction and isolated pure constituent of Mallotus peltatus: an ethnomedicine from Andaman Islands. Virol J. 2012;9:98. doi:10.1186/1743-422x-9-98

61. de Souza LM, Sassaki GL, Romanos MT, Barreto-Bergter E. Structural characterization and anti-HSV-1 and HSV-2 activity of glycolipids from the marine algae Osmundaria obtusiloba isolated from Southeastern Brazilian coast. Mar Drugs. 2012; 10:918-931. doi:10.3390/md10040918

62. Cheng HY, Yang CM, Lin TC, Lin LT, Chiang LC, Lin CC. Excoecarianin, isolated from phyllanthus urinaria linnea, inhibits herpes simplex virus type 2 infection through inactivation of viral particles. Evid Based Complement Alternat Med. 2009;20 11:259103.

63. Farahani M. Anti-herpes simplex virus effect of camellia sinesis, echiumamoenum and nerium oleander. J Appl Environ Microbiol. 2014;2:102-105.

64. Astani A, Navid MH, Schnitzler P. Attachment and penetration of acyclovir-resistant herpes simplex virus are inhibited by Melissa officinalis extract. Phytother Res. 2014;28:1547-1552. doi:10.10 02/ptr.5166

65. Shakeri A, Sahebkar A, Javadi B. Melissa officinalis L. A review of its traditional uses, phytochemistry and pharmacology. J Ethnopharmacol. 2016;188:204-228. doi:10.10 16/j.jep.2016.05.010

66. Tan WC, Jaganath IB, Manikam R, Sekaran SD. Evaluation of antiviral activities of four local Malaysian Phyllanthus species against herpes simplex viruses and possible antiviral target. Int J Med Sci. 2013;10:1817-1829. doi:10.7150/ijms.6902

67. Benzekri R, Bouslama L, Papetti A, Hammami M, Smaoui A, Limam F. Anti HSV-2 activity of Peganum harmala (L.) and isolation of the active compound. Microb Pathog. 2018;114:291-298. doi:10.1016/j.micpath.2017.12.017

68. Sabatino M, Fabiani M, Božovi'c M, et al. Experimental data based machine learning classification models with predictive ability to select in vitro active antiviral and non-toxic essential oils. Molecules. 2020;25:2452-2469. doi:10.3390/molecules25102452

69. Treml J, Gazdová M, Šmejkal K, Šudomová M, Kubatka P, Hassan STS. Natural products-derived chemicals: breaking barriers to novel anti-HSV drug development. Viruses. 2020;12. doi: $10.3390 /$ v12020154

70. Cavalcanti JF, de Araujo MF, Gonçalves PB, et al. Proposed anti-HSV compounds isolated from Simira species. Nat Prod Res. 2018;32:2720-2723. doi:10.1080 14786419.2017.1375914

71. Donalisio M, Nana HM, Ngane RA, et al. In vitro anti-Herpes simplex virus activity of crude extract of the roots of Nauclea latifolia Smith (Rubiaceae). BMC Complement Altern Med. 2013;13:266. doi:10.1186/1472-6882-13-266

72. Sagar S, Kaur M, Minneman KP. Antiviral lead compounds from marine sponges. Mar Drugs. 2010;8:2619-2638. doi:10.3390/ md8102619

73. Rosales PF, Bordin GS, Gower AE, Moura S. Indole alkaloids: 2012 until now, highlighting the new chemical structures and biological activities. Fitoterapia. 2020;143:104558. doi:10.1016/ j.fitote. 2020.104558
74. Mat Rashid Z, Andriani Y, Shaari K, et al. Induction of apoptosis and anti HSV-1 activity of 3-(Phenethylamino) demethyl(oxy) aaptamine from a Malaysian Aaptos aaptos. J Chem Pharm Res. 2015;2015:330-341.

75. Chin LW, Cheng YW, Lin SS, et al. Anti-herpes simplex virus effects of berberine from Coptidis rhizoma, a major component of a Chinese herbal medicine, Ching-Wei-San. Arch Virol. 2010;155:1933-1941. doi:10.1007/s00705-010-0779-9

76. Hishiki T, Kato F, Tajima S, et al. Hirsutine, an indole alkaloid of uncaria rhynchophylla, inhibits late step in dengue virus lifecycle. Front Microbiol. 2017;8:1674. doi:10.3389/fmicb.2017.01674

77. Quintana VM, Selisko B, Brunetti JE, et al. Antiviral activity of the natural alkaloid anisomycin against dengue and Zika viruses. Antiviral Res. 2020;176:104749. doi:10.1016/j.antiviral.2020. 104749

78. $\mathrm{Xu} \mathrm{W}$, Zhang M, Liu H, et al. Antiviral activity of aconite alkaloids from Aconitum carmichaelii Debx. Nat Prod Res. 2019;33:1486-1490. doi:10.1080/14786419.2017.1416385

79. Su B, Cai C, Deng M, Liang D, Wang L, Wang Q. Design, synthesis, antiviral activity, and SARs of 13a-substituted phenanthroindolizidine alkaloid derivatives. Bioorg Med Chem Lett. 2014;24:2881-2884. doi:10.1016/j.bmcl.2014.04.101

80. Ren G, Ding G, Zhang H, et al. Antiviral activity of sophoridine against enterovirus 71 in vitro. $J$ Ethnopharmacol. 2019;236:124-128. doi:10.1016/j.jep.2019.02.045

81. Jia YL, Wei MY, Chen HY, Guan FF, Wang CY, Shao CL. (+)and (-)-Pestaloxazine A, a pair of antiviral enantiomeric alkaloid dimers with a symmetric spiro[oxazinane-piperazinedione] skeleton from pestalotiopsis sp. Org Lett. 2015;17:4216-4219. doi:10.1021/acs.orglett.5b01995

82. Xiong HR, Shen YY, Lu L, et al. The inhibitory effect of Rheum palmatum against coxsackievirus B3 in vitro and in vivo. Am $J$ Chin Med. 2012;40:801-812. doi:10.1142/s0192415x12500607

83. Pan QM, Li YH, Hua J, Huang FP, Wang HS, Liang D. Antiviral matrine-type alkaloids from the rhizomes of Sophora tonkinensis. J Nat Prod. 2015;78:1683-1688. doi:10.1021/acs.jnatprod.5b00325

84. Nwodo UU, Ngene AA, Iroegbu CU, Onyedikachi OA, Chigor VN, Okoh AI. In vivo evaluation of the antiviral activity of Cajanus cajan on measles virus. Arch Virol. 2011;156:1551-1557. doi:10.1007/s00705-011-1032-x

85. Sun N, Sun P, Lv H, et al. Matrine displayed antiviral activity in porcine alveolar macrophages co-infected by porcine reproductive and respiratory syndrome virus and porcine circovirus type $2 . S c i$ Rep. 2016;6:24401. doi:10.1038/srep24401

86. Varghese FS, Kaukinen P, Gläsker S, et al. Discovery of berberine, abamectin and ivermectin as antivirals against chikungunya and other alphaviruses. Antiviral Res. 2016;126:117-124. doi:10.1016/j.antiviral.2015.12.012

87. Abdulkhaleq LA, Assi MA, Abdullah R, Zamri-Saad M, TaufiqYap YH, Hezmee MNM. The crucial roles of inflammatory mediators in inflammation: a review. Vet World. 2018;11:627-635. doi:10.14202/vetworld.2018.627-635

88. Lawrence T, Willoughby DA, Gilroy DW. Anti-inflammatory lipid mediators and insights into the resolution of inflammation. Nat Rev Immunol. 2002;2:787-795. doi:10.1038/nri915

89. Grivennikov SI, Greten FR, Karin M. Immunity, inflammation, and cancer. Cell. 2010;140:883-899. doi:10.1016/j.cell.2010.01.025

90. Triantafilou M, Gamper FGJ, Haston RM, et al. Membrane sorting of toll-like receptor (TLR)-2/6 and TLR2/1 heterodimers at the cell surface determines heterotypic associations with CD36 and intracellular targeting. J Biol Chem. 2006;281:31002-31011. doi:10.1074/jbc.M602794200

91. Herrington FD, Carmody RJ, Goodyear CS. Modulation of NF$\kappa \mathrm{B}$ signaling as a therapeutic target in autoimmunity. $J$ Biomol Screen. 2015;21:1087057115617456. doi:10.1177/10870571156 17456 
92. Ramos I, Fernandez-Sesma A. Modulating the innate immune response to influenza A virus: potential therapeutic use of anti-inflammatory drugs. Front Immunol. 2015;6:361. doi:10.33 89/fimmu.2015.00361

93. Nizri E, Irony-Tur-Sinai M, Lory O, Orr-Urtreger A, Lavi E, Brenner T. Activation of the cholinergic anti-inflammatory system by nicotine attenuates neuroinflammation via suppression of Th1 and Th17 responses. J Immunol. 2009;183:6681-6688. doi:10.40 49/jimmunol.0902212

94. Lakhan SE, Kirchgessner A. Anti-inflammatory effects of nicotine in obesity and ulcerative colitis. J Transl Med. 2011;9:129. doi:10.1186/1479-5876-9-129

95. Ito C, Itoigawa M, Furukawa A, et al. Quinolone alkaloids with nitric oxide production inhibitory activity from Orixa japonica. J Nat Prod. 2004;67:1800-1803. doi:10.1021/np0401462

96. Remppis A, Bea F, Greten HJ, et al. Rhizoma Coptidis inhibits LPS-induced MCP-1/CCL2 production in murine macrophages via an AP-1 and NFkappaB-dependent pathway. Mediators Inflamm. 2010;2010:194896. doi:10.1155/2010/194896

97. Li F, Wang HD, Lu DX, et al. Neutral sulfate berberine modulates cytokine secretion and increases survival in endotoxemic mice. Acta Pharmacol Sin. 2006;27:1199-1205. doi:10.1111/j.17457254.2006.00368.x

98. Zhang Q, Piao XL, Piao XS, Lu T, Wang D, Kim SW. Preventive effect of Coptis chinensis and berberine on intestinal injury in rats challenged with lipopolysaccharides. Food Chem Toxicol. 2011;49:61-69. doi:10.1016/j.fct.2010.09.032

99. Li HM, Wang YY, Wang HD, et al. Berberine protects against lipopolysaccharide-induced intestinal injury in mice via alpha 2 adrenoceptor-independent mechanisms. Acta Pharmacol Sin. 2011;32:1364-1372. doi:10.1038/aps.2011.102

100. Wang H, Li K, Ma L, et al. Berberine inhibits enterovirus 71 replication by downregulating the MEK/ERK signaling pathway and autophagy. Virol J. 2017;14:2. doi:10.1186/s12985-0160674-4

101. Cronstein BN, Molad Y, Reibman J, Balakhane E, Levin RI, Weissmann G. Colchicine alters the quantitative and qualitative display of selectins on endothelial cells and neutrophils. J Clin Invest. 1995;96:994-1002. doi:10.1172/jci118147
102. Jang EJ, Kim HK, Jeong H, Ye SL, Hwang ES. Anti-adipogenic activity of the naturally occurring phenanthroindolizidine alkaloid antofine via direct suppression of PPAR $\gamma$ expression. Chem Biodivers. 2014;11:962-969. doi:10.1002/cbdv.201300365

103. Chou ST, Jung F, Yang SH, et al. Antofine suppresses endotoxin-induced inflammation and metabolic disorder via AMP-activated protein kinase. Pharmacol Res Perspect. 2017;5: e00337. doi:10.1002/prp2.337

104. Tang J, Raza A, Chen J, Xu H. A systematic review on the sinomenine derivatives. Mini Rev Med Chem. 2018;18:906-917. doi:10.2174/1389557517666171123212557

105. Choi YH, Shin EM, Kim YS, Cai XF, Lee JJ, Kim HP. Antiinflammatory principles from the fruits of Evodia rutaecarpa and their cellular action mechanisms. Arch Pharm Res. 2006;29: 293-297. doi:10.1007/bf02968573

106. Conway GA, Slocumb JC. Plants used as abortifacients and emmenagogues by Spanish New Mexicans. J Ethnopharmacol. 1979;1:241-261. doi:10.1016/s0378-8741(79)80014-8

107. Li W, Yang SY, Yan XT, et al. NF- $\mathrm{BB}$ inhibitory activities of glycosides and alkaloids from Zanthoxylum schinifolium stems. Chem Pharm Bull (Tokyo). 2014;62:196-202. doi:10.1248/cpb. c13-00759

108. Ling JY, Zhang GY, Cui ZJ, Zhang CK. Supercritical fluid extraction of quinolizidine alkaloids from Sophora flavescens Ait. and purification by high-speed counter-current chromatography. J Chromatogr A. 2007;1145:123-127. doi:10.1016/j.chroma.20 07.01 .080

109. Dai JP, Wang QW, Su Y, et al. Oxymatrine inhibits influenza A virus replication and inflammation via TLR4, p38 MAPK and NF-кB pathways. Int J Mol Sci. 2018;19:965. doi:10.3390/ ijms 19040965
Drug Design, Development and Therapy

\section{Publish your work in this journal}

Drug Design, Development and Therapy is an international, peerreviewed open-access journal that spans the spectrum of drug design and development through to clinical applications. Clinical outcomes, patient safety, and programs for the development and effective, safe, and sustained use of medicines are a feature of the journal, which has also

\section{Dovepress}

been accepted for indexing on PubMed Central. The manuscript management system is completely online and includes a very quick and fair peer-review system, which is all easy to use. Visit http://www. dovepress.com/testimonials.php to read real quotes from published authors. 